\title{
Effect of the Influent Substrate Concentration on Nitrogen Removal from Summer to Winter in Field Pilot-Scale Multistage Constructed Wetland-Pond Systems for Treating Low-C/N River Water
}

\author{
Tao Wang ${ }^{1,2,3,4,+}$, Liping Xiao ${ }^{1,+}$, Hongbin Lu ${ }^{2,3,5, *}$, Shaoyong $\mathrm{Lu}^{2,3, *}$, Xiaoliang Zhao ${ }^{4}$ and Fuchun Liu ${ }^{6}$ \\ 1 School of Environmental and Municipal Engineering, Qingdao University of Technology, \\ Qingdao 266033, China; 201831470025@mail.bnu.edu.cn (T.W.); xiaoliping@qut.edu.cn (L.X.) \\ 2 State Environmental Protection Scientific Observation and Research Station for Lake \\ Dongtinghu (SEPSORSLD), Chinese Research Academy of Environmental Sciences, Beijing 100012, China \\ 3 State Key Laboratory of Environmental Criteria and Risk Assessment, Chinese Research Academy of \\ Environmental Sciences, Beijing 100012, China \\ 4 College of Environmental Science and Engineering, Liaoning Technical University, Fuxin 123000, China; \\ zhaoxiaoliang2008@126.com \\ 5 College of Water Sciences, Beijing Normal University, Beijing 100875, China \\ 6 College of Life Science, Cangzhou Normal University, Cangzhou 061001, China; liufuchun168@126.com \\ * Correspondence: luhbhg@163.com (H.L.); lushy2000@163.com (S.L.) \\ + These authors contributed equally to this work.
}

\section{check for} updates

Citation: Wang, T.; Xiao, L.; Lu, H.; Lu, S.; Zhao, X.; Liu, F. Effect of the Influent Substrate Concentration on Nitrogen Removal from Summer to Winter in Field Pilot-Scale Multistage Constructed Wetland-Pond Systems for Treating Low-C/N River Water. Sustainability 2021, 13, 12456 https://doi.org/10.3390/ su132212456

Academic Editor: Agostina Chiavola

Received: 8 September 2021

Accepted: 6 November 2021

Published: 11 November 2021

Publisher's Note: MDPI stays neutral with regard to jurisdictional claims in published maps and institutional affiliations.

Copyright: (c) 2021 by the authors. Licensee MDPI, Basel, Switzerland. This article is an open access article distributed under the terms and conditions of the Creative Commons Attribution (CC BY) license (https:/ / creativecommons.org/licenses/by/ $4.0 /)$.
Abstract: The quality of micropolluted water is unstable and its substrate concentration fluctuates greatly. The goal is to predict the concentration effect on the treatment of nitrogen in a river with an actual low C/N ratio for the proposed full-scale Xiaoyi River estuary wetland, so that the wetland project can operate stably and perform the water purification function effectively in the long term. Two pilot-scale multistage constructed wetland-pond (MCWP) systems (S1 and S2, respectively) based on actual engineering with the same "front ecological oxidation ponds, two-stage horizontal subsurface flow constructed wetlands and surface flow constructed wetlands (SFCWs) as the core and postsubmerged plant ponds" as the planned process were constructed to investigate the effect of different influent permanganate indexes $\left(\mathrm{COD}_{\mathrm{Mn}}\right)$ and total nitrogen $(\mathrm{TN})$ contents on nitrogen removal from micropolluted river water with a fixed $\mathrm{C} / \mathrm{N}$ ratio from summer to winter in the field. The results indicate that the TN removal rate in the S1 and S2 systems was significant $(19.56 \%$ and $34.84 \%$, respectively). During the process of treating this micropolluted water with a fixed $\mathrm{C} / \mathrm{N}$ ratio, the influent of S2 with a higher $\mathrm{COD}_{\mathrm{Mn}}$ concentration was conducive to the removal of TN. The TN removal rate in S2 was significantly affected by the daily highest temperature. There was significant nitrogen removal efficiency in the SFCWs. The $\mathrm{C} / \mathrm{N}$ ratio was a major determinant influencing the nitrogen removal rate in the SFCWs. The organic matter release phenomenon in SFCWs with high-density planting played an essential role in alleviating the lack of carbon sources in the influent. This research strongly supports the rule that there is seasonal nitrogen removal in the MCWPs under different influent substrate concentrations, which is of guiding significance for practical engineering.

Keywords: multistage constructed wetland pond; micropolluted river water; total nitrogen; seasonal temperature change

\section{Introduction}

With an increasing number of human activities, aquatic environments around the world, such as groundwater, rivers, lakes, and other surface water, have been polluted to varying degrees [1]. Micropolluted water refers to water polluted by organic matter with part of the water quality index exceeding the Class III standard requirement for surface water quality (GB 3838-2002, China). Due to excessive industrialization and extensive 
farming practices, nitrogen-containing pollutants that cannot be effectively controlled during industrial and agricultural production will enter nearby surface water bodies along with sewage or rainwater. The pollutant concentrations in natural water bodies are usually in the low range and have not received significant attention before. In summary, micropolluted water generally has the characteristics of a relatively low chemical oxygen demand (COD) $(<10 \mathrm{mg} / \mathrm{L})$, high nitrogen content, and low $\mathrm{C} / \mathrm{N}$ ratio [2]. Due to these pollutants being continuously discharged into the natural environment, the environmental bearing capacity of the surrounding water will inevitably decline. For example, excessive nitrogen-containing nutrients lead algae to take up excess nitrogen, grow and propagate, which leads to the eutrophication of water bodies and seriously affects the life activities of other aquatic organisms [3,4]. Worse, the accumulation of nitrogen in drinking water threatens human health [5]. Therefore, the issue of $\mathrm{N}$ pollution in surface water merits more attention in China and many other countries.

Constructed wetlands (CWs) are a type of wastewater treatment technology based on nature. Due to their advantages of simplicity, ecological economy, high efficiency, low consumption, and strong resistance to impact load, CWs have been applied worldwide in recent decades [6,7]. When the permanganate index $\left(\mathrm{COD}_{\mathrm{Mn}}\right)$ concentration in the influent is less than $6 \mathrm{mg} / \mathrm{L}, 5.3 \%$ to $50.0 \%$ of the total nitrogen (TN) can be removed by a horizontal subsurface flow constructed wetland (HSCW) or vertical flow constructed wetland (VFCW) [8-10]. Therefore, CWs have great potential to solve the issue of nitrogen removal from micropolluted water.

TN removal from wastewater by CWs occurs primarily through denitrification by microorganisms [11,12]. Other processes, such as anaerobic ammonium oxidation (anammox), plant absorption, filler adsorption, and ammonia volatilization, are generally found to have little effect $[13,14]$. The temperature is the primary environmental factor that affects nitrogen removal, and denitrifiers are extremely demanding in the living environment. Denitrifiers have excellent metabolic activity in the temperature range from $25{ }^{\circ} \mathrm{C}$ to $35^{\circ} \mathrm{C}$ [15]. The rate of the denitrification reaction clearly dropped at $15^{\circ} \mathrm{C}$, and the reaction proceeded weakly at $5{ }^{\circ} \mathrm{C}$ [16]. Low temperature affected the life activity of denitrifiers, with a $9 \%$ decrease in the denitrification rate for every $1{ }^{\circ} \mathrm{C}$ drop in temperature [17]. The activity of ammonia-oxidizing bacteria (AOB) and nitrite-oxidizing bacteria (NOB) was affected by the sudden drop in temperature $\left(20^{\circ} \mathrm{C}\right.$ to $\left.10{ }^{\circ} \mathrm{C}\right)$, resulting in a $20 \%$ decrease in the nitrification rate [18]. Therefore, it is particularly important to ensure that there is still good nitrogen removal in micropolluted water with CWs under temperature changes.

Multistage CWs can greatly improve the performance of nitrogen removal and temperature resistance compared with single-stage CWs. Surface-vertical flow CWs could remove an average of $54.0 \%$ and $53.9 \%$ of ammonia nitrogen $\left(\mathrm{NH}_{4}{ }^{+}-\mathrm{N}\right)$ and $\mathrm{TN}$ from river water, respectively, and their purification performance is significantly higher than that of single-stage CWs [19]. Another study suggested that the TN removal efficiency by a multistage CW was $25.90 \%$ [20]. The efficiency of TN purification may be affected by environmental factors. Earlier, some scholars predicted the concentration of total Kjeldahl nitrogen (TKN) in the effluent of CWs under different conditions related to the hydraulic retention time (HRT) at a specific temperature [21]. However, few people have studied the influence of the temperature change on the TN concentration in the effluent of multistage CWs. There may be a high correlation between air temperature and removal rate. If this hypothesis is confirmed, it will be useful to predict the effect of nitrogen removal and effluent quality by monitoring the temperature change, which is of great importance to make timely responses to climate change. Additionally, as an important factor in polluted water substrates, the $\mathrm{C} / \mathrm{N}$ ratio determines the adequacy and efficiency of microbial denitrification reactions. Most studies pay more attention to the effects of different $\mathrm{C} / \mathrm{N}$ ratios on nitrogen removal in CWs. Ding et al. [22] studied the nitrogen removal effect of HSCWs with different influent $\mathrm{C} / \mathrm{N}$ ratio levels and showed that increasing the $\mathrm{C} / \mathrm{N}$ ratio in influent water can greatly improve the denitrification effect. Wu et al. [23] studied the effect of different $\mathrm{C} / \mathrm{N}$ ratios on surface flow constructed wetlands (SFCWs) and showed that 
the CWs had good treatment performance when the $\mathrm{C} / \mathrm{N}$ ratio was 5 . The denitrification characteristics of microorganisms showed that the ability of microorganisms to reduce nitrite was strong when the $\mathrm{C} / \mathrm{N}$ ratio was less than 5 . When the $\mathrm{C} / \mathrm{N}$ ratio was greater than 5, the ability of microorganisms to reduce nitrate was stronger [24]. In general, the characteristics of low COD in micropolluted water make it possible to enhance nitrogen removal by adding carbon sources to $C W$ s to raise the $C / N$ ratio of the influent substrate. However, in actual full-scale CWs, there are some disadvantages, such as difficult carbon source dosing operations and high-cost pressure. Due to the quality of micropolluted water being greatly affected by seasonal factors, there is a question about the variability of nitrogen removal efficiency in CWs when the carbon and nitrogen content in low $\mathrm{C} / \mathrm{N}$ ratio water increases or decreases simultaneously (with a fixed $\mathrm{C} / \mathrm{N}$ ratio). There is less research on this issue. Only by studying the effect of different carbon and nitrogen contents on the nitrogen removal process in $\mathrm{CWs}$ at low $\mathrm{C} / \mathrm{N}$ ratios can we take effective measures to improve the nitrogen removal efficiency during actual projects. Additionally, the effect of plants in a high-density planted CW as an additional denitrifying carbon source on nitrogen removal from low- $\mathrm{C} / \mathrm{N}$ river water is worth studying.

The Xiaoyi River entering the lake in northern China undertakes the tailwater of sewage treatment plants, industrial wastewater, and agricultural and aquaculture nonpoint source sewage from cities and counties along the watershed. The TN index of the river water has been in the inferior Class $\mathrm{V}$ of environmental quality standards for surface water (GB 3838-2002, China) for a long time, which directly threatens the water quality safety of the lake. In the downstream section of the river and at the entrance of the lake, a full-scale Xiaoyi River estuary wetland (using the "front ecological oxidation pond, twostage HSCWs and SFCW as the core and post-submerged plant pond" near-natural water purification process) with an engineering scale of $200,000 \mathrm{~m}^{3} /$ day and an area of $1.98 \mathrm{~km}^{2}$ is proposed for construction to form an ecological buffer zone by the lake and improve the carrying capacity of the water ecological environment in the watershed. However, the actual effects of the project are unknown. To predict the purification effect of the actual wetland project on the TN and to investigate several problems mentioned above, two field-based pilot-scale multistage constructed wetland-pond (MCWP) systems were built. We made the following assumptions: (1) there is a high correlation between the air temperature and removal rate in MCWPs; (2) the units of MCWPs hold different nitrogen removal efficiencies when the $\mathrm{C} / \mathrm{N}$ is a fixed value with different $\mathrm{C}$ and $\mathrm{N}$ concentrations; and (3) when multistage CWs are used for treating water bodies with a low $\mathrm{C} / \mathrm{N}$ ratio, plants play a key role.

\section{Materials and Methods}

\subsection{Construction of the MCWPS}

In this study, two sets of parallel, equivalently scaled-down systems (namely, S1 and S2) and two MCWPs were based on a full-scale wetland project (the same process as this study). Each system includes 7 treatment units in total, namely, a raw water tank (RWT), an ecological pond (EP), an oxidation pond (OP), a first-level horizontal subsurface flow constructed wetland (FHSCW), a second-level horizontal subsurface flow constructed wetland (SHSCW), an SFCW, and a submerged plant pond (SPP) (Figure 1). Each treatment unit is connected to each other with a $20 \mathrm{~mm}$ diameter water pipe. The outer surface of each unit is wrapped with tin foil and black plastic bags from inside to outside to prevent algal growth. The unit configurations and operating parameters are shown in Table 1. The design of the HRT is based on the technical specification of constructed wetlands for wastewater treatment engineering (HJ 2005-2010) and the technical guide on constructed wetland water purification systems (DB 37/T 3394-2018). 


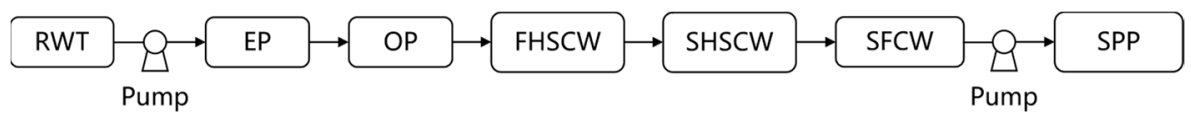

Figure 1. System process flow plan.

Table 1. Unit configurations and operating parameters.

\begin{tabular}{|c|c|c|c|c|c|c|c|}
\hline Unit & RWT & EP & OP & FHSCW & SHSCW & SFCW & SPP \\
\hline Dimension/mm & $\Phi 65 \times 90$ & $\begin{array}{c}200 \times 140 \times \\
2000\end{array}$ & $\begin{array}{c}630 \times 300 \times \\
1500\end{array}$ & $\begin{array}{c}1000 \times 260 \times \\
1250\end{array}$ & $\begin{array}{c}1000 \times 260 \times \\
1250\end{array}$ & $\begin{array}{c}1000 \times 800 \times \\
500\end{array}$ & $\begin{array}{c}500 \times 300 \times \\
1550\end{array}$ \\
\hline $\begin{array}{l}\text { Water } \\
\text { level/mm }\end{array}$ & & 1800 & 1080 & 1200 & 1200 & 450 & 1500 \\
\hline HRT/d & & 0.22 & 0.89 & 0.54 & 0.54 & 1.57 & 0.89 \\
\hline
\end{tabular}

$\Phi$ : Diameter $\times$ height.

The multistage CW system was composed of a two-stage HSCW (including an FHSCW and SHSCW with identical structures and dimensions, with only the level elevation of the FHSCW being higher than that of the SHSCW, a difference used to allow water to flow by gravity) and an SFCW in series. A schematic diagram of the HSCW and SFCW is shown in Supplementary Figure S1. The substrate layer in the middle of the HSCW is the primary functional area for biofilm hanging, which is filled with steel slag and gravel with a 10-20 mm particle size at a ratio of 1:4, with a thickness of $840 \mathrm{~mm}$. The inlet and outlet areas on both sides are filled with large gravel with a $20-40 \mathrm{~mm}$ particle size, which plays the role of retaining suspended particles in the water body, with a thickness of $80 \mathrm{~mm}$. The surface layer of the bed is paved with fine gravel measuring $5-8 \mathrm{~mm}$ in size, primarily for the rooting of emergent plants, and is $200 \mathrm{~mm}$ thick. The support layer at the bottom of the SFCW is paved with gravel measuring $10-20 \mathrm{~mm}$ in size, at a thickness of $100 \mathrm{~mm}$, while the upper substrate is soil for the rooting of emergent plants, at a thickness of $300 \mathrm{~mm}$. For the pond system (EP, OP, and SPP), the device configurations are rectangular-shaped, with no filling substrate inside, and are instead hydroponically cultivated with plants, as described in Section 2.2. The relevant parameters of the pond installations are shown in Table 1.

\subsection{Startup and Operation of the MCWPS}

The plants were carefully excavated from the river near the site for cleaning and cultivating in ponds and CWs, respectively, in August. The systems were submerged in tap water immediately after planting to allow for the development of plants and microbes. One Nymphaea tetragona plant was planted in the EP. Myriophyllum spicatum was grown hydroponically in OP and SPP at densities of 26 plants $/ \mathrm{m}^{2}$ and 33 plants $/ \mathrm{m}^{2}$, respectively. In the HSCWs and SFCW, the planting densities of Iris pseudacorus L. were 5 plants $/ \mathrm{m}^{2}$ and 35 plants $/ \mathrm{m}^{2}$, respectively. These aquatic plants are the primary plant types in the natural wetland and were selected not only because they are cheap, easy to obtain, hardy, and have good water purification effects, but also because they are of great significance for the effective conservation and rational development of native plant resources. After 1 month, the influents were continuously dosed into the systems to start the experiment. The experiment operated officially from 21 September to 28 November 2019, for a total of 68 days.

A total of $350 \mathrm{~L}$ of river water was pumped from the river and stored in the RWT every day. The influent water was diluted with tap water 2 times (S1, $150 \mathrm{~L}$ to $300 \mathrm{~L}$ ) and 1.5 times (S2, $200 \mathrm{~L}$ to $300 \mathrm{~L})$. A peristaltic pump was used to control the hydraulic loading rate of 160 $\mathrm{mL} / \mathrm{min}$ to pump the river water from the RWT into the EP. Then, inflow freely flowed into the SFCW by relying on the water level difference. The effluent from the SFCW flowed into a bucket and was then pumped into the SPP by a peristaltic pump. Lastly, the effluent from the system was discharged into the sewer. Inlet and outlet water was sampled every 5 days. Water samples were determined in 1 day, and every sample was tested in triplicate. The raw water quality is shown in Table 2 . After the raw water was diluted, the influent $\mathrm{C} / \mathrm{N}$ 
ratio, $\mathrm{COD}_{\mathrm{Mn}}, \mathrm{TN}$, and $\mathrm{NH}_{4}{ }^{+}-\mathrm{N}$ in the $\mathrm{S} 1$ and $\mathrm{S} 2$ systems were $0.81,3.02 \mathrm{mg} / \mathrm{L}, 3.72 \mathrm{mg} / \mathrm{L}$, and $0.52 \mathrm{mg} / \mathrm{L}$ and $0.82,3.39 \mathrm{mg} / \mathrm{L}, 4.15 \mathrm{mg} / \mathrm{L}$, and $0.71 \mathrm{mg} / \mathrm{L}$, respectively.

Table 2. Average inflow, outflow, and removal rates of $\mathrm{TN}, \mathrm{NH}_{4}{ }^{+}-\mathrm{N}, \mathrm{COD}_{\mathrm{Mn}}, \mathrm{TP}$, and $\mathrm{pH}$ in each unit of the $\mathrm{S} 1$ and $\mathrm{S} 2$ MCWP systems ${ }^{\text {a }}$.

\begin{tabular}{|c|c|c|c|c|c|c|c|c|c|c|c|c|c|c|c|c|}
\hline \multirow{3}{*}{ Parameter } & \multicolumn{8}{|c|}{ S1 } & \multicolumn{8}{|c|}{ S2 } \\
\hline & \multirow{2}{*}{$\underset{(\mathrm{mg} / \mathrm{L})}{\text { Influent }}$} & \multicolumn{6}{|c|}{$\begin{array}{l}\text { Effluent } \\
\text { (mg/L) }\end{array}$} & \multirow{2}{*}{$\begin{array}{c}\text { Removal } \\
\text { Efficiency } \\
\left(^{(\%)}\right)^{b}\end{array}$} & \multirow{2}{*}{$\begin{array}{c}\text { Influent } \\
(\mathrm{mg} / \mathrm{L})\end{array}$} & \multicolumn{6}{|c|}{$\begin{array}{c}\text { Effluent } \\
\text { (mg/L) }\end{array}$} & \multirow{2}{*}{$\begin{array}{c}\text { Removal } \\
\text { Efficiency } \\
(\%)\end{array}$} \\
\hline & & EP & OP & FHSCW & SHSCW & SFCW & $\overline{\text { SPP }}$ & & & EP & OP & FHSCW & SHSCW & SFCW & SPP & \\
\hline $\mathrm{TN}$ & 3.72 & 3.42 & 3.25 & 3.45 & 3.36 & 3.15 & 3.04 & 19.56 & 4.15 & 4.26 & 3.81 & 3.97 & 3.90 & 3.33 & 2.87 & 34.84 \\
\hline $\mathrm{NH}_{4}^{+}-\mathrm{N}$ & 0.52 & 0.46 & 0.43 & 0.53 & 0.38 & 0.44 & 0.37 & - & 0.71 & 0.57 & 0.57 & 0.63 & 0.50 & 0.55 & 0.61 & 8.37 \\
\hline $\mathrm{COD}_{\mathrm{Mn}}$ & 3.02 & 3.09 & 3.58 & 3.56 & 2.18 & 2.37 & 4.01 & - & 3.39 & 2.80 & 3.35 & 3.53 & 3.19 & 2.75 & 3.63 & - \\
\hline $\mathrm{TP}^{\mathrm{Mn}}$ & 0.11 & 0.10 & 0.11 & 0.35 & 0.47 & 0.45 & 0.45 & - & 0.08 & 0.06 & 0.06 & 0.27 & 0.31 & 0.25 & 0.23 & - \\
\hline pH & 8.02 & 8.10 & 8.24 & 8.38 & 8.63 & 8.59 & 8.80 & - & 8.18 & 8.20 & 8.32 & 8.54 & 8.83 & 8.80 & 8.89 & - \\
\hline
\end{tabular}

${ }^{a}$ Arithmetic mean of 15 samples (3 replicates/sample) collected every five days during the experimental period. ${ }^{\mathrm{b}}$ "-" indicates the removal efficiency is negative.

\subsection{Method of Determination and Analysis}

The TN was analyzed using the alkaline potassium persulfate digestion UV spectrophotometric method (HJ 636-2012). The $\mathrm{NH}_{4}{ }^{+}-\mathrm{N}$ content was analyzed by Nessler's reagent spectrophotometry $(\mathrm{HJ} 535-2009)$. $\mathrm{COD}_{\mathrm{Mn}}$ was analyzed by acidic potassium permanganate oxidation method (GB 11892-89). In the HSCWs and SFCWs of the S1 and S2 systems, three representative plants of high, medium, and low heights were selected at the beginning of the experiment for plant height observation every 10 days. On the 21st day, the plant height had barely increased due to climate change, so the plants were reselected, and the plant heights were measured every 20 d. SPSS 26 and Origin 2019 were used for data analysis and graphing. The analysis was considered statistically significant when $p$ was less than 0.05 .

\section{Results and Discussion}

\subsection{TN Removal Effect in the EPs and OPs}

Since the systems were fed with actual surface water, the water quality fluctuated widely (see Figure 2). The front ecological oxidation ponds were used as a pretreatment process for multistage $\mathrm{CW}$, and the primary design purpose was to remove SS from the influent $[25,26]$. In addition, EP and OP also acted as necessary parts related to nitrogen transformation. The TN removal efficiency in the EP of S1 was $7.27 \pm 20.80 \%(p>0.05)$. However, the effluent concentration of TN was $2.65 \%$ higher than the influent concentration in the EP of S2. It was noted that the removal rate curve of the EP for S2 had a minimum value on the 10th day. The influent $\mathrm{TN}$ concentration was too low and was significantly lower than the effluent TN concentration. This result is due to the fluctuation of the TN concentration in the actual river inflow. Due to the oxygen secretion of floating plants in the $\mathrm{EP}$ and the distribution of dissolved oxygen (DO) at different water levels, upper aerobic, middle anoxic, and bottom anaerobic environments were formed, which would facilitate the nitrification and denitrification of microorganisms $[27,28]$. In addition, the nitrogen in the influent likely accumulates in the sediment deposited at the bottom of the pond; using this approach may also be one of the methods of nitrogen removal. However, when the flow was disturbed, the sediment would release nitrogen for the second time, which would increase the nitrogen content in the effluent and decrease the removal efficiency. Therefore, it is worth noting here, based on our research results, that the nitrogen removal effect in S1 was better than that in S2, which was not inconsistent with our hypothesis. In general, higher influent $C$ concentrations were more conducive to microbial denitrification. This finding may be due to the greater fluctuation in the influent TN concentration in S2 than in S1, which made the average influent TN concentration higher than that of S1. Therefore, the adverse effect of the influent $\mathrm{N}$ impact load in the EP of S2 was greater than the beneficial effect caused by the adequacy of the $\mathrm{C}$ source, which directly contributed to an increase in the nitrogen content of the effluent in S2. 


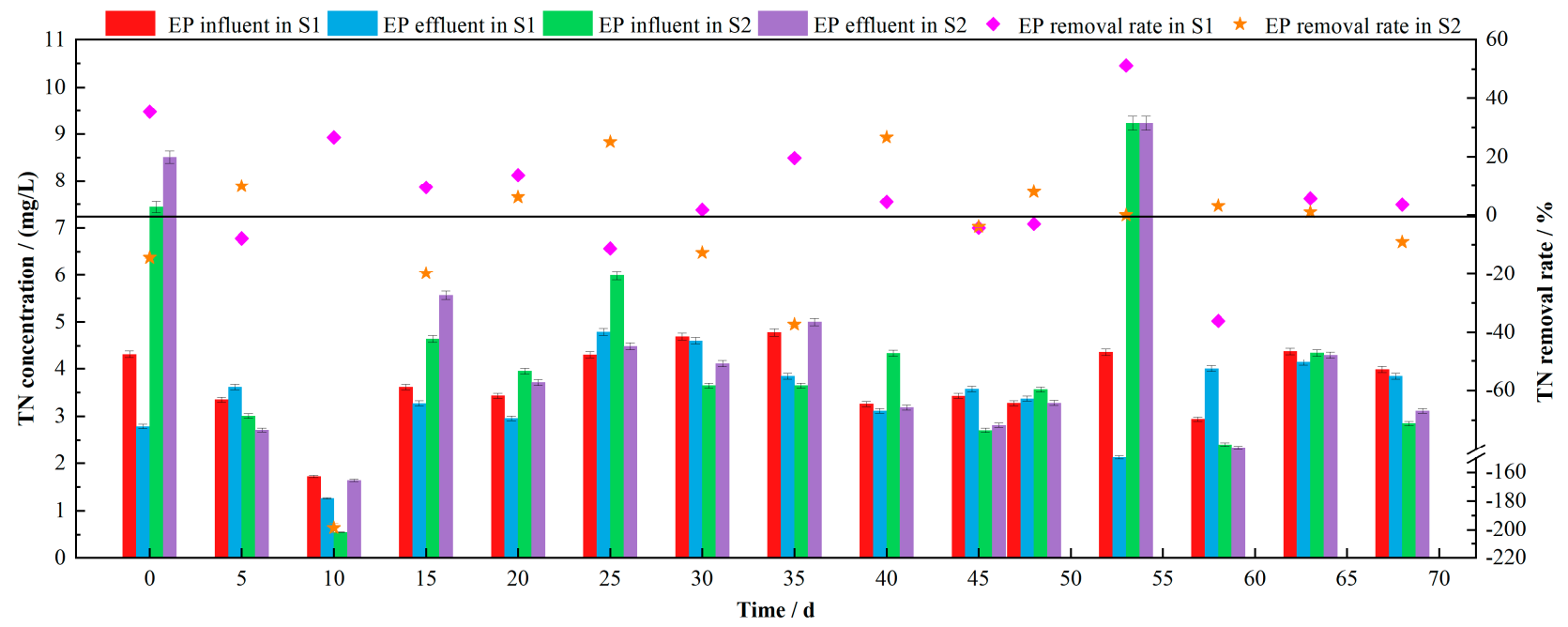

Figure 2. TN removal effect in the EP of S1 and S2.

The removal efficiency in the OP reached a maximum on the 10th day, at $59.79 \%$ and $71.29 \%$ in S1 and S2, respectively. Overall, the TN removal rates in the OP of S1 and S2 were $6.47 \pm 22.91 \%$ and $9.88 \pm 22.57 \%$, respectively, which was in accordance with the removal efficiency of $7.71 \%$ reported by Wang et al. [29]. The results suggested that the OPs could not remove TN effectively for either S1 or S2 ( $p>0.05)$. The removal rate curves of S1 and S2 showed a similar trend (Figure 3). To enhance the shock load resistance of the system operation, OP coupled to multistage $\mathrm{CW}$ enables the influent to convert nitrogen to different forms in the pond first under aerobic conditions, and to finally complete the removal of nitrogen from the wastewater under the action of denitrifiers in multistage CW.

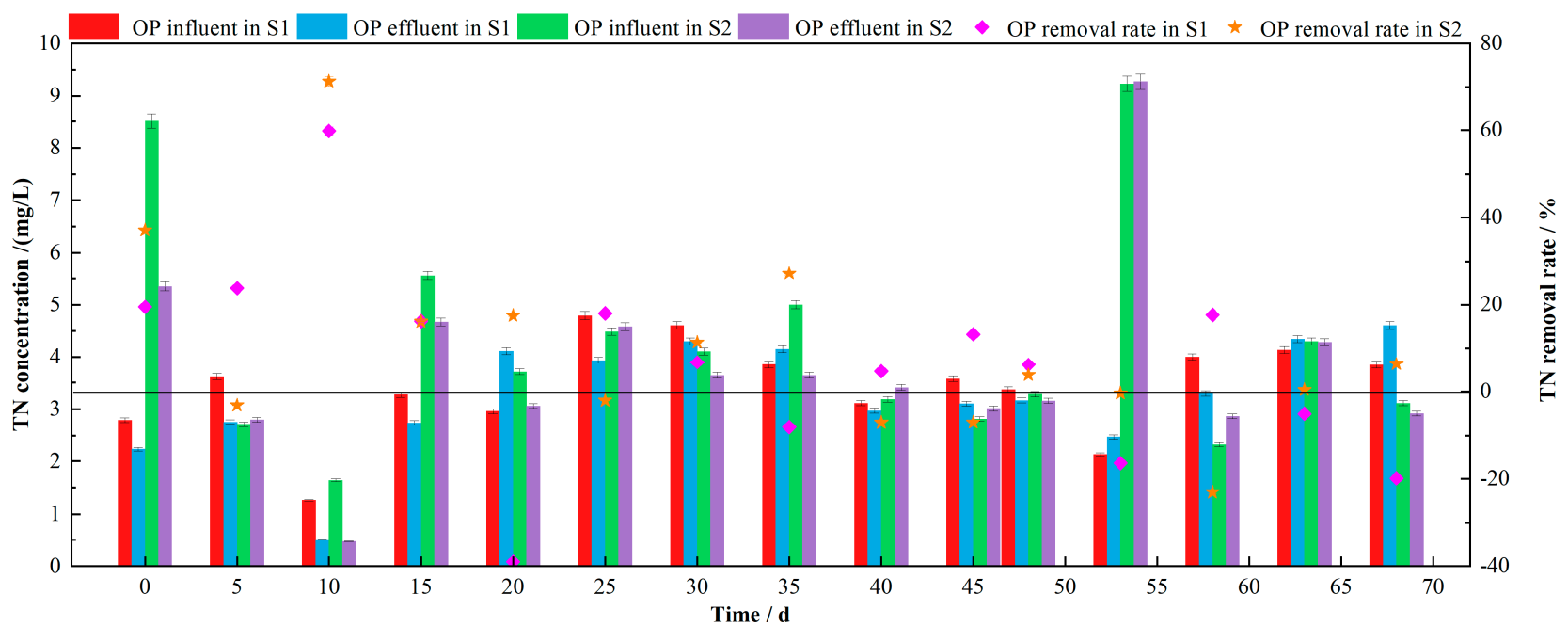

Figure 3. TN removal effect in the OP of S1 and S2.

\subsection{TN Removal Effect in the FHSCWs and SHSCWs}

The effluent TN concentrations in the FHSCW of S1 and S2 were $6.15 \%$ and $4.20 \%$ higher than the influent concentration, respectively. The release of nitrogen may result in elevated TN concentrations in the effluent of HSCWs. As a limiting factor, the lack of a carbon source in the system inflow restricts the removal effect of microbial denitrification on nitrogen. In addition, in HSCWs, limited oxygen supply capability is another important limiting factor. Therefore, the nitrification reaction process is the key to nitrogen removal [30]. HSCWs are limited by weak atmospheric oxygen exchange capacity and long-term saturation of plant oxygen secretion, with oxygen transfer rates of only 
$1-8 \mathrm{~g} /\left(\mathrm{m}^{2} \cdot \mathrm{d}\right)[31,32]$, which is insufficient to support adequate nitrification reactions. When the dead microorganisms and plant residues in FHSCWs release nitrogen into the water, it affects the TN concentration in the effluent, resulting in a decrease in the removal rate and even a negative value [33]. As shown in Figure 4, the TN removal efficiency was relatively low in the FHSCW of S1 during the early period of operation. Microorganisms may be affected by the increase in effluent $\mathrm{pH}$ (see Table 2) caused by the release of steel slag alkalinity, resulting in a weakness in biological activity. In addition, this characteristic may occur because the plant is still in an adaptation stage. The plants grew slowly during the early stages and the rotten roots were likely to release nitrogen. After the 10th day, the operation of the FHSCW entered a stable stage, and the biofilm on the surface of the filler gradually matured and stabilized. Plants in the FHSCWs of the S1 and S2 systems had growth rates of $8 \%$ and $14 \%$ from the 20th $d$ and 40 th $d$, respectively (Supplementary Figure S2). Thus, the removal effect was improved.

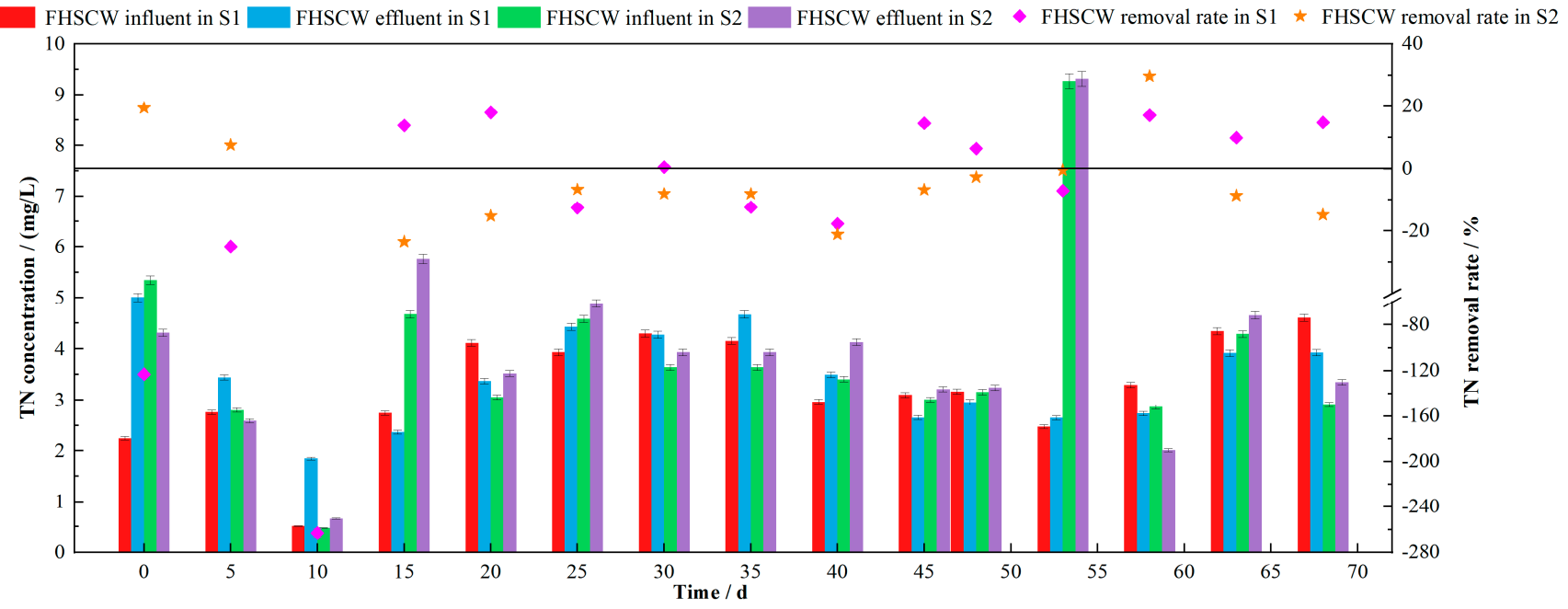

Figure 4. TN removal effect in the FHSCW of S1 and S2.

The TN removal efficiencies in the SHSCWs of S1 and S2 were $0.74 \pm 14.45 \%$ and $3.08 \pm 20.51 \%$, respectively. The trend in the removal rate curve of the S1 system for TN was basically consistent with that of the S2 system (see Figure 5). The removal rate of nitrogen was better during the middle stage, and the concentration in the outflow increased in the later stage. There was a good nitrogen removal effect in the SHSCW of S1 from the 15 th to the 40th day, with an average removal efficiency of $7.21 \%$. This result may be related to the good plant growth during this period. The plant growth rates were $10 \%$ and $9 \%$ from the 0th $d$ to 20th $d$ and 21st day to 40th day, respectively (Supplementary Figure S2). When the system was operated on the 45th day, the TN concentration in the effluent was higher than that in the influent, and the removal rate was negative. The reason may be that the plant residues released nitrogen to the water body, which had a specific effect on the TN concentration in the effluent. After that, the removal rate increased again. The stable operation period in S2 was longer than that in S1. From the 15th to the 48th days, the average removal efficiency was $13.84 \%$, and the highest removal efficiency was $29.31 \%$ in the SHSCW of S2. When the system operated to the 53rd day, it was affected by the impact of the TN concentration on the inflow $(9.31 \mathrm{mg} / \mathrm{L})$, resulting in the elevated TN concentration in the outflow, and the removal efficiency was negative. After the 53rd day, as the nitrogen load rate in the influent returned to normal, the removal rate increased gradually. These results show that there was a specific nitrogen removal capacity in the SHSCW of both S1 and S2, but the ability to resist the impact load was weak. The fluctuation of the nitrogen concentration in the influent had a great influence on the nitrogen removal performance, which made the TN concentration in the effluent unstable. The reason was likely relevant to the bacterial community in SHSCWs. The lower $\mathrm{C} / \mathrm{N}$ ratio and the lower 
temperature may reduce the activity of denitrifiers in SHSCWs. Therefore, denitrification would be weakened, causing an elevated effluent TN concentration when the nitrogen impact load occurs. The difference between the SHSCWs of the two systems was that in the midterm stable operation phase, compared with $S 1$, there was a higher nitrogen removal rate (nearly 2 times) and a longer maintenance time in S2, which was likely relevant to the higher carbon concentration in the influent of S2.

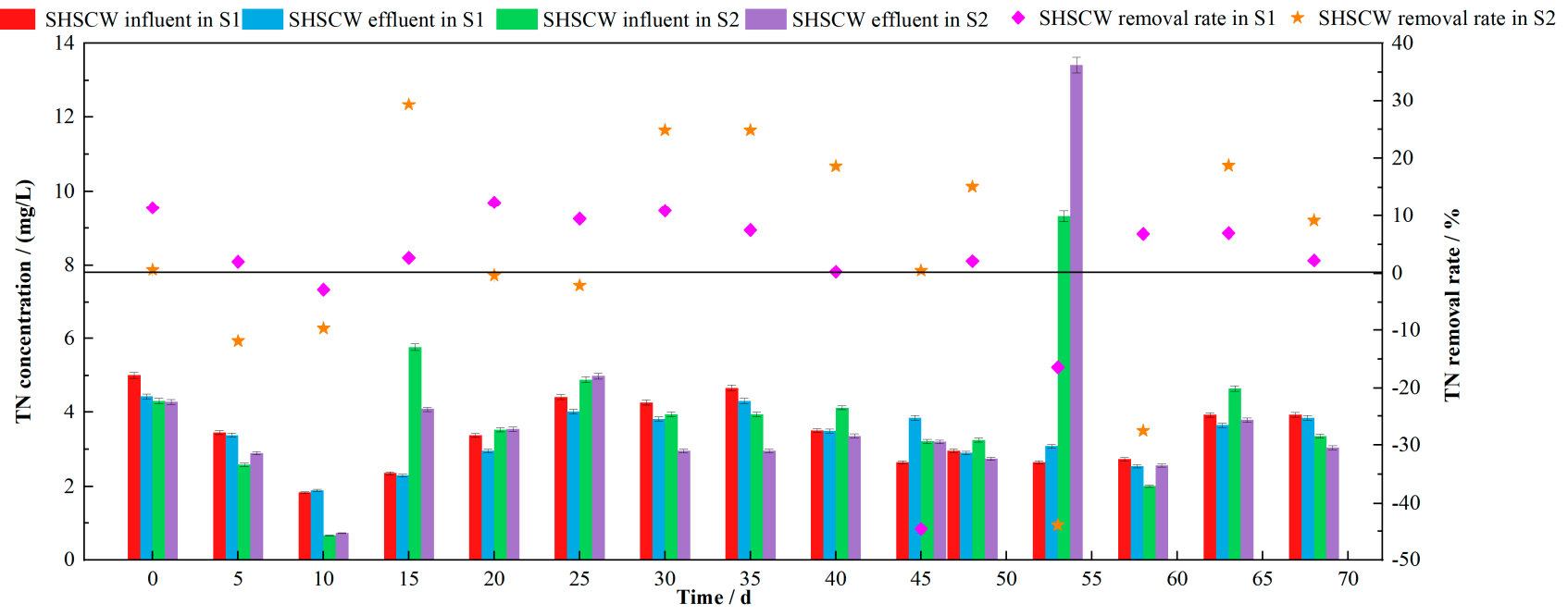

Figure 5. TN removal effect in the SHSCW of S1 and S2.

HSCWs have been widely used in wastewater nitrogen removal because they can form an aerobic zone, anoxic zone, and anaerobic zone similar to those formed by the $\mathrm{A}^{2} / \mathrm{O}$ process around the rhizosphere under the effect of oxygen release from plant roots. There have been some pilot-scale HSCWs that have achieved high treatment effects during nitrogen removal from domestic sewage. However, there were also some HSCWs during the nitrogen removal from micropolluted water, in which the removal effect was negligible, which was primarily relevant to the different $\mathrm{C} / \mathrm{N}$ ratios of the tested water. When the tested water of CWs in cold areas is the tailwater of urban sewage plants, the influent is mostly characterized by a low $\mathrm{C} / \mathrm{N}$ ratio [34]. The lack of a $\mathrm{C}$ source inhibits the denitrification process of microorganisms. In a previous study on the removal effect of

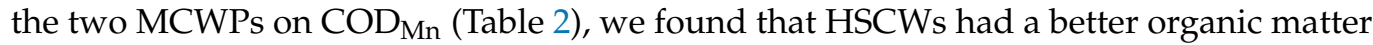
removal effect than other treatment units during operation, indicating that the majority of C sources were consumed by heterotrophic microorganisms in the aerobic area of HSCWs. When the inflow was pushed to the denitrification functional area, the easily degradable carbon sources were exhausted. The rest were mostly refractory organics, which could not provide more electron donors. Therefore, the denitrification reaction was inhibited [35], resulting in poor nitrogen removal from HSCWs.

\subsection{TN Removal Effect in the SFCWs and SPPS}

The TN removal rates in the SFCWs of S1 and S2 were $7.82 \pm 13.90 \%(p<0.05)$ and $13.79 \pm 22.66 \%(p<0.05)$, respectively. High-density planting SFCWs not only make up for a large amount of organic carbon sources for water influent in the form of root exudates but also have the tallest plant height with an average height of more than $60 \mathrm{~cm}$ throughout the process (Supplementary Figure S2). The exact amount of substances that plants can release has not yet been studied, but some reports give a general range, usually within $5-25 \%$ of photosynthetically fixed carbon. The greater biomass provides the possibility for the roots to exude more organic matter. The removal efficiency curves of S1 and S2 show a similar trend; that is, they are roughly distributed in an " $\mathrm{M}^{\prime}$ shape (Figure 6). In the SFCW of S1, the average removal efficiency was $20.55 \%$ during the first 15 days of operation, and the highest was 35.05\%; from the 20th day to the 35th day, the average removal efficiency 
was only $-6.04 \%$; and from the 40th day to the end of the operation, the average removal efficiency was $8.47 \%$. In the SFCW of S2, the average removal efficiency was $26.33 \%$ during the first 10 days of operation, and the highest was $63.24 \%$; from the 15 th to the 35 th days, the average removal efficiency was only $0.57 \%$; and from the 40th day to the end of the operation, the average removal efficiency was $17.85 \%$. The results suggest that the removal performance of TN from the SFCW of S1 and S2 is better during the early and later stages of operation, which is likely relevant to the release of organic matter from plant tissue to promote the denitrification of microorganisms. At the beginning of the operation, the plants were still in the adaptation stage. The organic matter released by the root exudates or rotted roots acted as the carbon source of denitrification and compensated for the lack of a carbon source in the SFCWs. At a later stage of the operation, the temperature gradually decreased, and plant growth entered the withering stage. The litter of emergent plants dissolved and released organic matter [36], providing a carbon source for denitrification. In addition, the covering layer formed by litter residue was conducive to thermal insulation in SFCWs. This was also the reason why there was still a given nitrogen removal performance during the later period. In terms of the removal rate, the removal efficiency in the SFCW of S2 was better than that in the SFCW of S1, indicating that a high concentration of carbon was conducive to the removal of nitrogen in SFCWs.

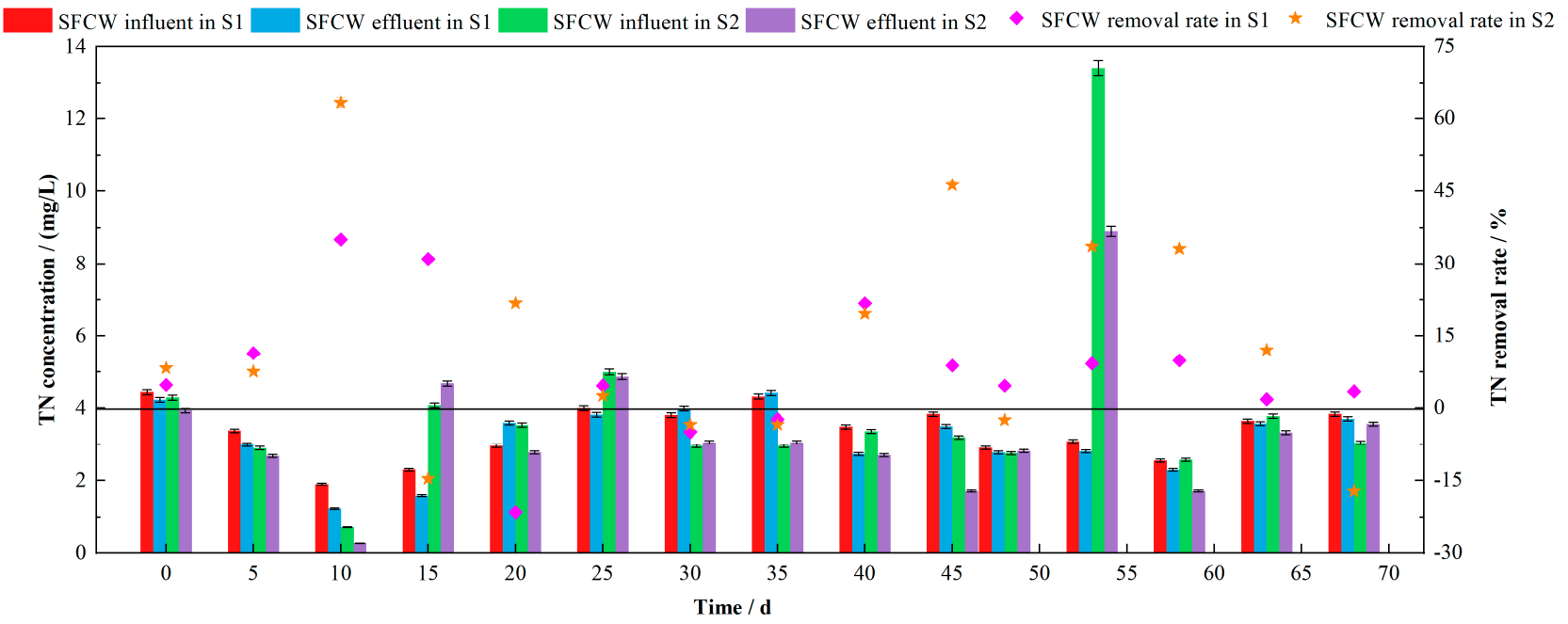

Figure 6. TN removal effect in the SFCW of S1 and S2.

Since the most significant nitrogen removal effect occurred in SFCWs, the TN removal rate in SFCWs was set as group $\mathrm{A}$, and the $\mathrm{COD}_{\mathrm{Mn}}, \mathrm{TN}, \mathrm{NH}_{4}{ }^{+}-\mathrm{N}, \mathrm{TP}$, and the $\mathrm{C} / \mathrm{N}$ ratio in the inflow of SFCWs were set as group B. Then, a canonical correlation analysis was conducted. The correlation coefficient was $0.628(p<0.05)$, and $\mathrm{A}=1$ was the TN removal rate in the SFCW, $\mathrm{B}=-0.674 \mathrm{COD}-0.723 \mathrm{TN}+0.122 \mathrm{NH}_{4}{ }^{+}-\mathrm{N}-0.078 \mathrm{TP}+1.374 \mathrm{C} / \mathrm{N}$ ratio. The results indicate that from summer to winter, the $\mathrm{C} / \mathrm{N}$ ratio is an important determinant of the nitrogen removal effect in SFCWs. The $\mathrm{C} / \mathrm{N}$ ratio was negatively related to the $\mathrm{TN}$ concentration in the influent, which indicated that the higher the influent nitrogen loading was, the more unfavorable the nitrogen removal in SFCWs. Intriguingly, the TN removal rate in SFCWs was negatively related to the COD in the influent, indicating that organic substance release occurred in SFCWs, which played a key role in alleviating the lack of $C$ sources in the inflow. The lack of a carbon source will not be conducive to denitrification, which will contribute to the accumulation of nitrate nitrogen $\left(\mathrm{NO}_{3}{ }^{-} \mathrm{N}\right)$ in the system. Therefore, uncovering how to solve the lack of a C source in CWs is of great importance to improving the TN removal performance.

The TN removal efficiencies in the SPPs of S1 and S2 were $4.86 \pm 18.43 \%$ and $18.31 \pm 25.11 \%(p<0.05)$, respectively. The results showed that the nitrogen removal effect in S2 was more obvious than that in S1. The TN removal efficiency reached the 
highest values of $42.24 \%$ and $72.23 \%$ in the SPPs of S1 and S2 on the 15th and 10th days, respectively (see Figure 7). The decay and decomposition of submerged plants have a great influence on the TN concentration in the effluent. Plant residues dissolved and released nitrogen into the water body, which influenced the TN content in the outflow. However, the organic matter released by the decaying plant residue provided a $C$ source for denitrification. Moreover, Myriophyllum spicatum grown hydroponically in ponds may take up more nutrients than emergent macrophyte species in CWs [37]. To determine why this difference occurred, first, entire plants were submerged in water. They can more easily take up nutrients by using organs (such as leaves) other than the water body roots than emergent species. Second, submerged plants have higher tissue nutrient concentrations than emergent species [38] due to their lower need for carbon-rich structural tissue for vertical growth. Third, many submerged plant species grow rapidly, with high biomass yields of up to $1 \mathrm{~kg}$ dry mass $/ \mathrm{m}^{2}$ [39]. Nutrients are reportedly removed from water bodies by macrophyte harvesting, with rates ranging from $<0.1$ to $125 \mathrm{mg} \mathrm{N} \mathrm{m}^{-2} \mathrm{~d}^{-1}$ [40]. Therefore, the submerged plant-microorganism interaction system was an important reason for the excellent nitrogen removal in ponds. It is also worth noting that the TN concentration in the OP $(4.26 \mathrm{mg} / \mathrm{L})$ of the S2 system was significantly higher than that in the SPP $(3.33 \mathrm{mg} / \mathrm{L})$ in this study (Table 2). The higher nitrogen concentration would limit the uptake of nitrogen by the submerged plants, which is one of the reasons for the better nitrogen removal performance in the SPP than in the OP. After that, the removal rate declined, which may be related to seasonal variations in temperature. The decline in temperature inhibited microbial metabolism and plant activity in the pond, which was not conducive to denitrification by denitrifiers and plant uptake. Compared with the $\mathrm{OP}$, the nitrogen removal rate in the OP and SPP was greatly affected by the temperature, which also reflected that the nitrogen removal pathway in the pond was primarily dominated by the denitrification of microbes.

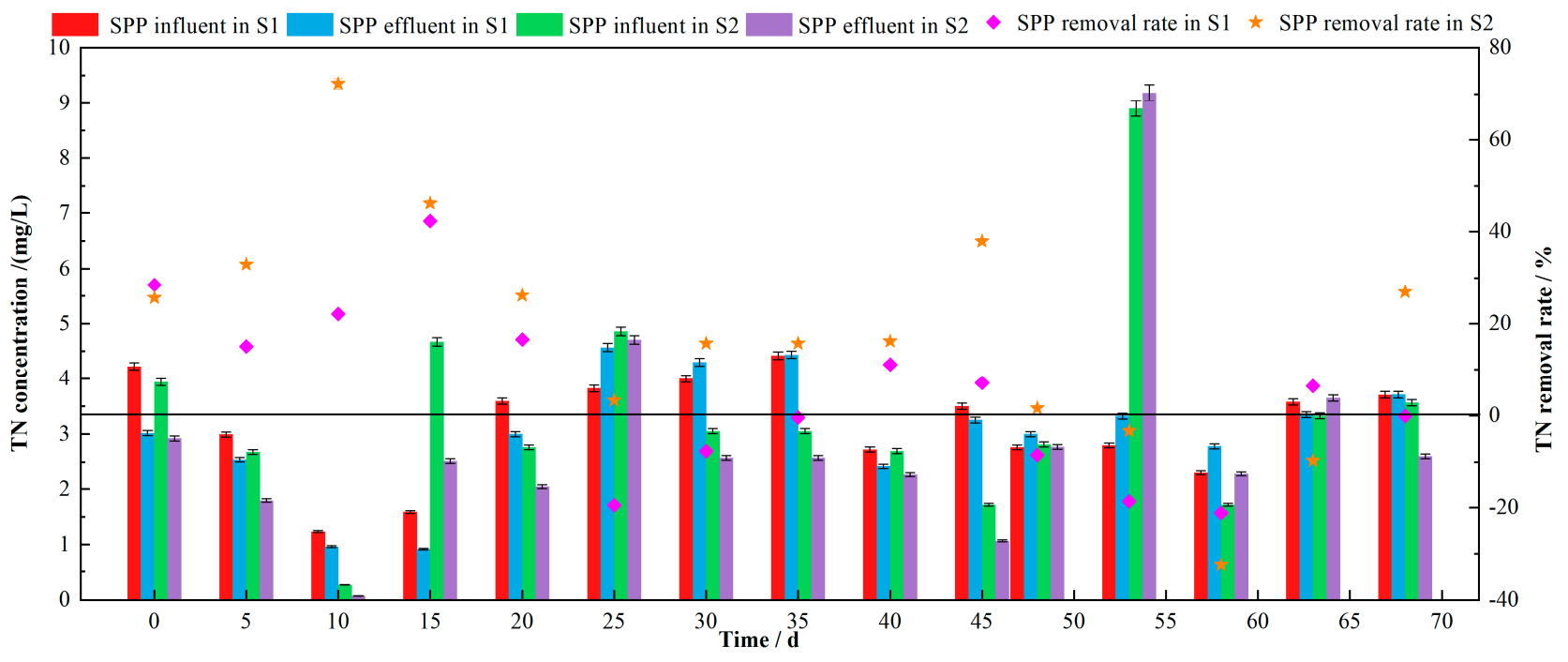

Figure 7. TN removal effect in the SPP of S1 and S2.

According to our previous research [41], the phenomenon of "the release of organic matter is greater than the removal effect, causing an elevated effluent $\mathrm{COD}_{\mathrm{Mn}}$ concentration" in SFCWs and SPPs (Table 2), which also provided strong support for excellent nitrogen removal performance in SFCWs, was in turn consistent with the results in the present paper.

The adequacy of the carbon source available to microorganisms in water relative to the denitrification process was a primary influencing factor restricting the efficiency of bacterial denitrification, especially in the winter [42-44]. A C/ $\mathrm{N}$ ratio that is too high or too low would reportedly cause a large amount of $\mathrm{N}_{2} \mathrm{O}$ release. Under a $\mathrm{C} / \mathrm{N}$ ratio of 5 , the $\mathrm{CW}$ had better treatment performance and essentially no $\mathrm{N}_{2} \mathrm{O}$ release [23]. In a system 
with an insufficient $C$ source, denitrification can be promoted by using the carbon source of the system itself (plant residues or plant root exudates) [45-48]. In view of the fact that SFCWs use high-density planting to treat micropolluted water with a low organic load rate, the proportion of organic matter secreted by plant roots should not be underestimated. The $\mathrm{CO}_{2}$ fixed by the photosynthesis of emerged plants in CWs will be partly released into the rhizosphere soil in the form of root exudates, primarily as oxalic acid, benzoic acid, citric acid, glutaric acid, and acetic acid, which are considered to be the primary components of the denitrified carbon source in plant root exudates [49], as well as some non-nutrients, such as fatty acid methyl ester (FAME) and fatty acid amide (FAA) [50,51]. Wheat root exudates have an obvious rhizosphere effect on denitrifiers, which can promote root denitrification [52]. However, the number of denitrifiers in unplanted CW or nonrhizospheres was significantly lower than that in the plantings of Eichhornia crassipes and Cyperus alternifolius CW [53,54]. Moreover, the DOC secretion ability, as compounds secreted by different species of emergent macrophytes, is also very different; therefore, they have different purification efficiencies for sewage. The concentrations of oxalic acid and malic acid secreted by Canna indica were reportedly 6 times and 2 times higher, respectively, than those secreted by Zizania latifolia [55]. According to a previous study, macrophytes that secrete more DOCs can promote the denitrification rate [56]. However, the release of DOCs by macrophytes simultaneously increases the COD in the effluent, which coincides with the results of this research. Intriguingly, root exudates are the characteristic substances to which plants instinctively respond as environmental factors during the process of adapting to the environment. For example, in this experiment, to adapt to the low environmental $\mathrm{C} / \mathrm{N}$, the plants in SFCWs and SPPs at the initial period promoted the denitrification reaction by secreting organic carbon from their roots. However, from summer to winter, the photosynthetic rate of plants was reduced, and the carbon fixation capacity of plants was lost at low temperatures. The release rate of DOCs from Picea rubens Sarg. at $10^{\circ} \mathrm{C}$ was approximately half of that at $20^{\circ} \mathrm{C}$, and the secretion rate decreased with the decreasing temperature $[57,58]$. When the experiment was operated in the middle stage, the organic matter secreted by plant roots was reduced by the influence of low temperatures, which decreased the denitrification efficiency. However, with this experiment operating during the later stage, plant growth was affected by low temperatures into the withering period. The organic matter dissolved and released from the plant litter in the SFCW created conditions for denitrification and provided a carbon source.

Lu et al. [36] found that the fastest release of pollutants due to the decay of plant tissue occurred within the first $24 \mathrm{~h}$. At an HRT of $5 \mathrm{~d}$, a hydraulic load rate of $8.7 \mathrm{~cm} / \mathrm{d}$, and an influent COD load rate of $13.7 \mathrm{~g} /\left(\mathrm{m}^{2} \cdot \mathrm{d}\right)$, the COD released by plant tissues accounted for $38 \%$ of the removal load. During the decay and decomposition of Potamogeton crispus, the release of carbon in the short term (which peaked on the 14th day) would cause secondary pollution of the water body [59]. The various forms of nitrogen released by the plants were also affected by the plant species [60]. In the actual environment, the decomposition of plant residues led to the release of DOCs, which was also affected by the temperature. The highest COD release of $10 \mathrm{~g}$ of Myriophyllum verticillatum at $25^{\circ} \mathrm{C}$ was $97.69 \mathrm{mg} / \mathrm{L}$ (the temperature gradient was $5^{\circ} \mathrm{C}, 15^{\circ} \mathrm{C}, 25^{\circ} \mathrm{C}$, and $35^{\circ} \mathrm{C}$ ) [61]. At low temperatures, decayed plant litter can not only provide an additional carbon source but can also be used as a heat preservation measure in CWs. Practice has shown that covering is a very efficient way to solve the freezing problem. A simulation of the isolated CW by computer modeling showed that proper isolation can effectively solve the freezing problem even when the temperature is below $20^{\circ} \mathrm{C}$. This type of covering includes natural and artificial covering. Natural covering is the plant litter and snow layer, and artificial covering is the $20-40 \mathrm{~cm}$ insulation layer for hay, straw, and polystyrene [62-64].

\subsection{TN Total Removal Effect in the MCWPS}

The overall removal performance in the MCWPs is shown in Figure 8. The TN removal efficiency in the MCWPs of S1 and S2 were $19.56 \pm 19.88 \%(p<0.05)$ and $34.84 \pm 23.92 \%$ 
$(p<0.05)$, respectively. Similarly, Li et al. [65] evaluated the effect of a large-scale SFCWpond system on the purification of micropolluted water (influent $\mathrm{COD}_{\mathrm{Mn}}$ concentration of $6.16 \mathrm{mg} / \mathrm{L}, \mathrm{TN}$ concentration of $1.71 \mathrm{mg} / \mathrm{L}$, and $\mathrm{C} / \mathrm{N}$ ratio of 3.6) and showed that the TN removal rates of an SFCW planted with emergent aquatic plants and an SFCW planted with submerged aquatic plants were only $19.4 \%$ and $3.6 \%$, respectively. The total TN removal rate could only reach $42.9 \%$ with an HRT of $18.5 \mathrm{~d}$. Zeng [8] studied CWs to treat micropolluted water with $\mathrm{COD}_{\mathrm{Mn}}$ concentrations of $1.35-5.64 \mathrm{mg} / \mathrm{L}$ and $\mathrm{TN}$ concentrations of $0.044-2.82 \mathrm{mg} / \mathrm{L}$. The results showed that the average monthly TN removal rate was only 5.3-38.2\%. Yang et al. [20] conducted a study on a hybrid CW consisting of a VFCW and an SFCW to treat micropolluted water with influent $\mathrm{COD}_{\mathrm{Mn}}$ concentrations of $3.15-6.25 \mathrm{mg} / \mathrm{L}$ and TN concentrations of $0.27-1.20 \mathrm{mg} / \mathrm{L}$. The results showed that the average TN removal rate was only $25.94 \%$, as limited by low organic matter, which was consistent with the results of this study.

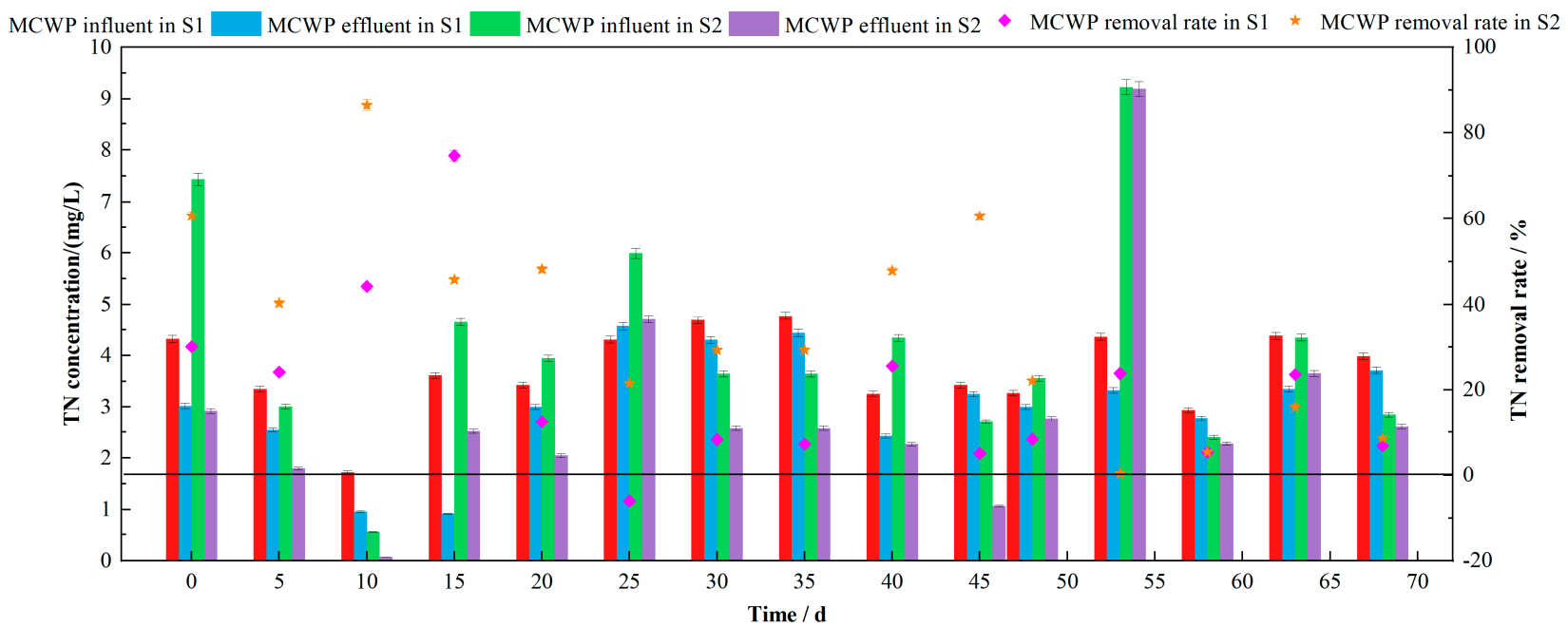

Figure 8. TN total removal effect in the MCWP of S1 and S2.

From the research results, the nitrogen removal effect in S2 was better than that in S1 (as shown in Table 2, the average removal rate in S2 was nearly 2 times that of S1), which showed that during the process of treating the inflow with the same $\mathrm{C} / \mathrm{N}$ ratio, a higher carbon content was conducive to nitrogen removal. In this process, multistage CWs with FHSCW-SHSCW-SFCW systems as the core were the primary means to achieve nitrogen removal. The denitrification reaction primarily occurs during the latter part of the whole process. As this study was conducted using the $\mathrm{CW}$-pond process to treat river water with a low $\mathrm{C} / \mathrm{N}$ ratio without additional carbon sources, the lack of a carbon source in the influent was a direct factor limiting the denitrification reaction. However, when the influent concentrations were below background values, the organic matter concentration could increase when passing through the CW system [66]. The high-density planting SFCWs released organic substances that acted as additional electron donors through root exudates and decomposing plant litter, which greatly improved the denitrification effect. Additionally, DO was gradually consumed as the influent was deeply purified in the later units, thus continuously expanding the anoxic environment and facilitating the denitrification reaction. The FHSCW-SHSCW-SFCW of the S1 system removed $23.39 \%$ of the COD compared to $\mathrm{S} 2(8.45 \%)$. The average effluent COD concentration of $2.37 \mathrm{mg} / \mathrm{L}$ resulted in a TN removal rate of $-7.94 \%$ in the core CWs of the S1 system, while that of the S2 system was as high as $15.21 \%$ (influent COD concentration was $2.75 \mathrm{mg} / \mathrm{L}$ ). SFCWs are the key to nitrogen removal in hybrid CWs [67]. Despite the organic matter release in the SFCW of the S1 system (the COD concentration increased from $2.18 \mathrm{mg} / \mathrm{L}$ to $2.37 \mathrm{mg} / \mathrm{L}$, probably because the lower influent concentration was more susceptible to external environmental carbon sources), the $\mathrm{C} / \mathrm{N}$ ratio of 0.71 was still lower than that of 
0.82 in the S2 system (Table 2), which is one of the reasons why the TN removal rate (13.79\%) in the SFCW of the S2 system was higher than that of S1 (7.82\%). The higher influent COD concentration $(2.75 \mathrm{mg} / \mathrm{L})$ and the elevated effluent COD due to the release of pollutants were important reasons for the significant nitrogen removal efficiency $(18.31 \%)$ in the SPP of the S2 system. The increase in the COD effluent concentration is primarily related to the decomposition of aquatic plants grown in the SPP. Plant decay is a complex process affected by the chemical properties of plant residues and a combination of environmental factors, starting with the leaching of complex organic matter and ending with the release of simple inorganic substances $[68,69]$. Three processes are broadly involved: physical leaching, the microbial decomposition of organic matter, and the degradation of insoluble substances [70]. Periodic plant growth causes the release of large amounts of organic matter into the water from biofilms shed by the root system and dead plant residues [71,72], together with high microbial activity and low DO, providing ideal conditions for denitrification. The microbial metabolic pathway in which microbes breathe $\mathrm{NO}_{3}{ }^{-}-\mathrm{N}$ while decomposing organic substrates converts the pollutant $\mathrm{NO}_{3}{ }^{-}-\mathrm{N}$ into inert $\mathrm{N}_{2}$ gas, which makes up $78 \%$ of our atmosphere.

There was a similar trend between the TN removal rate of S1 and that of S2. The trend showed that the removal efficiency first rises and then gradually drops. With the high planting density method used in the SFCWs, the root exudates of emergent plants made up for the lack of a C source in the influent, promoted denitrification by microbes, and improved the nitrogen removal effect during the earlier period. The temperature was the key factor limiting nitrogen removal, and the seasonal temperature change was also a direct cause of the degradation of the system nitrogen removal performance. The time when the TN removal rate began to decline in S2 (45th day) was delayed by 30 days compared with S1 (15th day), which may be due to a thermal insulation layer formed by the plant litter in the SFCW. The layer provided good temperature conditions for denitrifiers. The organic matter that dissolved and released from plant residues provided the carbon source conditions for denitrification.

According to the classification of hybrid CWs by Vymazal [67], the core units of the pilot-scale devices built in this study, i.e., FHSCW-SHSCW-SFCW systems, are hybrid CWs with SFCWs. In terms of $\mathrm{NH}_{4}{ }^{+}-\mathrm{N}$ removal, Vymazal [67] showed that hybrid CWs with SFCWs removed $2.34 \pm 3.31 \mathrm{~g} \mathrm{NH}_{4}{ }^{+}-\mathrm{N} \mathrm{m}^{-2} \mathrm{~d}^{-1}$ on average. Vymazal et al. [73] analyzed a large data set and reported average removals of $0.83 \pm 6.56 \mathrm{~g} \mathrm{NH}_{4}{ }^{+}-\mathrm{N} \mathrm{m}^{-2} \mathrm{~d}^{-1}$ for HSCWs and $2.07 \pm 2.03 \mathrm{~g} \mathrm{NH}_{4}{ }^{+}-\mathrm{N} \mathrm{m}^{-2} \mathrm{~d}^{-1}$ for VFCWs. There was no significant difference in $\mathrm{NH}_{4}{ }^{+}-\mathrm{N}$ removal between single-stage VFCWs and hybrid CWs $(p>0.05)$; that is, the combination of various types of CWs, which include a VFCW, does not provide enhanced $\mathrm{NH}_{4}{ }^{+}-\mathrm{N}$ removal compared to a single VFCW. Instead of VFCWs, the S1 and S2 systems in this study used FHSCW-SHSCW-SFCW systems as the core to remove $0.25 \mathrm{~g} \mathrm{NH}_{4}{ }^{+}-\mathrm{N} \mathrm{m}^{-2} \mathrm{~d}^{-1}$ and $0.35 \mathrm{~g} \mathrm{NH}_{4}{ }^{+}-\mathrm{N} \mathrm{m}^{-2} \mathrm{~d}^{-1}$, respectively. The reason for the lower $\mathrm{NH}_{4}{ }^{+}-\mathrm{N}$ removal load may be related to the formation of biofilms in the SFCWs, which is described later. In addition, the $\mathrm{NH}_{4}{ }^{+}-\mathrm{N}$ removal loads of $66 \%$ and $69 \%$ for hybrid CWs of S1 and S2 systems were slightly lower than the $78 \% \mathrm{NH}_{4}{ }^{+}-\mathrm{N}$ removal rate reported by Vymazal [67] for hybrid CWs with SFCWs.

Unlike $\mathrm{NH}_{4}{ }^{+}-\mathrm{N}$, Vymazal [67] indicated that the most efficient system for the removal of TN was the hybrid CW, which included an SFCW stage in the treatment line and was able to remove an average of $4.24-5.12 \mathrm{~g} \mathrm{TN} \mathrm{m}^{-2} \mathrm{~d}^{-1}$. Linear fitting results revealed that the removed load of TN accounted for approximately $77 \%$ of the influent load. Various types of CWs provide different redox conditions that are suitable for enhancing the removal of TN. In the FHSCW-SHSCW-SFCW of the S1 and S2 systems, the influent TN load and removed load were $2.88 \mathrm{~g} \mathrm{TN} \mathrm{m}^{-2} \mathrm{~d}^{-1}$ and $1.97 \mathrm{~g} \mathrm{TN} \mathrm{m}^{-2} \mathrm{~d}^{-1}$ and $3.38 \mathrm{~g} \mathrm{TN} \mathrm{m}^{-2} \mathrm{~d}^{-1}$ and $2.42 \mathrm{~g} \mathrm{TN} \mathrm{m}^{-2} \mathrm{~d}^{-1}$, respectively. The removed load accounted for $68 \%$ and $72 \%$ of the influent load, respectively, which was basically consistent with the results of Vymazal.

To analyze the effect of the influent substrate concentration on the total removal rate comprehensively, the total TN removal rate in two MCWPs was set as group A, and 
the $\mathrm{COD}_{\mathrm{Mn}}, \mathrm{TN}, \mathrm{NH}_{4}{ }^{+}-\mathrm{N}, \mathrm{TP}$, and $\mathrm{C} / \mathrm{N}$ ratio in the inflow of two MCWPs were set as group B. A canonical correlation analysis was conducted. The correlation coefficient was $0.77(p<0.05)$, and $\mathrm{A}=1$ was the total $\mathrm{TN}$ removal rate, with $\mathrm{B}=0.306 \mathrm{COD}_{\mathrm{Mn}}-0.286$ $\mathrm{TN}+0.965 \mathrm{NH}_{4}{ }^{+}-\mathrm{N}-0.049 \mathrm{TP}+0.164 \mathrm{C} / \mathrm{N}$ ratio. From summer to winter, the $\mathrm{NH}_{4}{ }^{+}-\mathrm{N}$ concentration was an important determinant affecting the TN removal rate, followed by the $\mathrm{COD}_{\mathrm{Mn}}$. The results showed that on the background of an insufficient $\mathrm{C}$ source in the influent water, there was a highly positive correlation between the $\mathrm{NH}_{4}{ }^{+}-\mathrm{N}$ concentration and TN removal efficiency. As shown in Table 2, the influent $\mathrm{NH}_{4}{ }^{+}-\mathrm{N}$ concentration and TN removal efficiency of the S1 and S2 systems in this study were $0.52 \mathrm{mg} / \mathrm{L}$ and $19.56 \%$ and $0.71 \mathrm{mg} / \mathrm{L}$ and $34.84 \%$, respectively. In CWs, nitrification and denitrification are well-known processes of nitrogen transformation. However, anaerobic ammonia oxidation (anammox) challenges this theory. $\mathrm{NH}_{4}{ }^{+}-\mathrm{N}$ can be oxidized by $\mathrm{NO}_{2}{ }^{-}-\mathrm{N}$ into dinitrogen gas. Approximately $40 \%$ of $\mathrm{NH}_{4}{ }^{+}-\mathrm{N}$ was reportedly removed owing to the anammox in a CW [74]. Additionally, the newly discovered Nitrospira spp. that oxidize $\mathrm{NH}_{4}{ }^{+}-\mathrm{N}$ to $\mathrm{NO}_{3}{ }^{-}-\mathrm{N}$, i.e., the so-called complete ammonia oxidation (comammox), overturned the doctrine that the oxidation of $\mathrm{NH}_{4}{ }^{+}-\mathrm{N}$ and $\mathrm{NO}_{2}{ }^{-}-\mathrm{N}$ requires $\mathrm{AOB}$ and $\mathrm{NOB}$, respectively. The Candidatus Nitrospira inopinata that conducts the comammox reaction likely adjusted to low $\mathrm{NH}_{4}{ }^{+}-\mathrm{N}$ environments and overcame the competition for AOB survival [75]. Therefore, it is possible that bacteria oxidize $\mathrm{NH}_{4}{ }^{+}-\mathrm{N}$ to $\mathrm{NO}_{3}{ }^{-}-\mathrm{N}$ under low $\mathrm{NH}_{4}{ }^{+}-\mathrm{N}$ concentration conditions, which undoubtedly shortens the nitrogen conversion pathway and enhances the efficiency of nitrogen removal.

As shown in Table 2, pollutant release occurred in the SFCWs of the S1 and S2 systems, and the outflow concentration of $\mathrm{NH}_{4}{ }^{+}-\mathrm{N}$ increased by $16 \%$ and $10 \%$, respectively. Generally, SFCWs have better ammonia removal performance than HSCWs, which is attributed to good reoxygenation capacity for the growth of AOB [76], but the results of this study gave different results. This may be related to the formation of biofilms in the SFCWs. Qualitative identification and analysis of the gelatinous biofilm formed in the SFCW revealed that its constituents were Ulothrix and Euglenoides algae, which were distributed in suspension and were one of the important components of the microbial community $[77,78]$. However, this situation caused problems with wetland-atmosphere oxygen exchange, reduced the aeration of the water body, restricted the metabolism of aerobic bacteria, and ultimately hindered the removal of $\mathrm{NH}_{4}{ }^{+}-\mathrm{N}$ by the SFCWs.

\subsection{Effect of Temperature on Nitrogen Removal}

Low temperature was the key factor that restrained the nitrogen removal performance of MCWPs; therefore, it was necessary to discuss the effect of a change in season on the nitrogen removal efficiency in the two systems. As shown in Figure 9, with the system operating on the 10 th day (the air temperature ranged from $15^{\circ} \mathrm{C}$ to $30^{\circ} \mathrm{C}$ ), the air temperature began to decline. While the removal rate in the two systems showed a nonsynchronized drop, the nitrogen removal efficiency in S2 was more sensitive to the change in air temperature, and it fell synchronously with the temperature. The nitrogen removal efficiency in S1 fell rapidly after the 15th day (the highest removal rate was $74.67 \%$ ) and then maintained an average removal rate of $10.94 \%$ until the end of the experiment. After S2 reached the highest TN removal rate of $86.53 \%$ on the 10th day, the removal rate transitioned to a "plateau" due to the small fluctuation of the daily highest temperature (from the 15th day to the 40th day, the daily highest temperature was $13-25^{\circ} \mathrm{C}$, and the average daily highest temperature was $18.8^{\circ} \mathrm{C}$ ). In addition, the thermal insulation layer formed by the plant litter in the SFCW of S2 played an important role in preventing the wetland from being affected by the continuous decrease in the lowest temperature. After the 45th day (the highest daily temperature was $18^{\circ} \mathrm{C}$, and the lowest temperature was $4{ }^{\circ} \mathrm{C}$ ), the removal rate decreased rapidly with the temperature drop (the average removal efficiency was $10.49 \%$ ). Finally, the S2 removal efficiency was equivalent to that of S1, but it is worth noting that the time when the $\mathrm{TN}$ removal rate began to decline in $\mathrm{S} 2$ was delayed by 30 days compared with $\mathrm{S} 1$. 


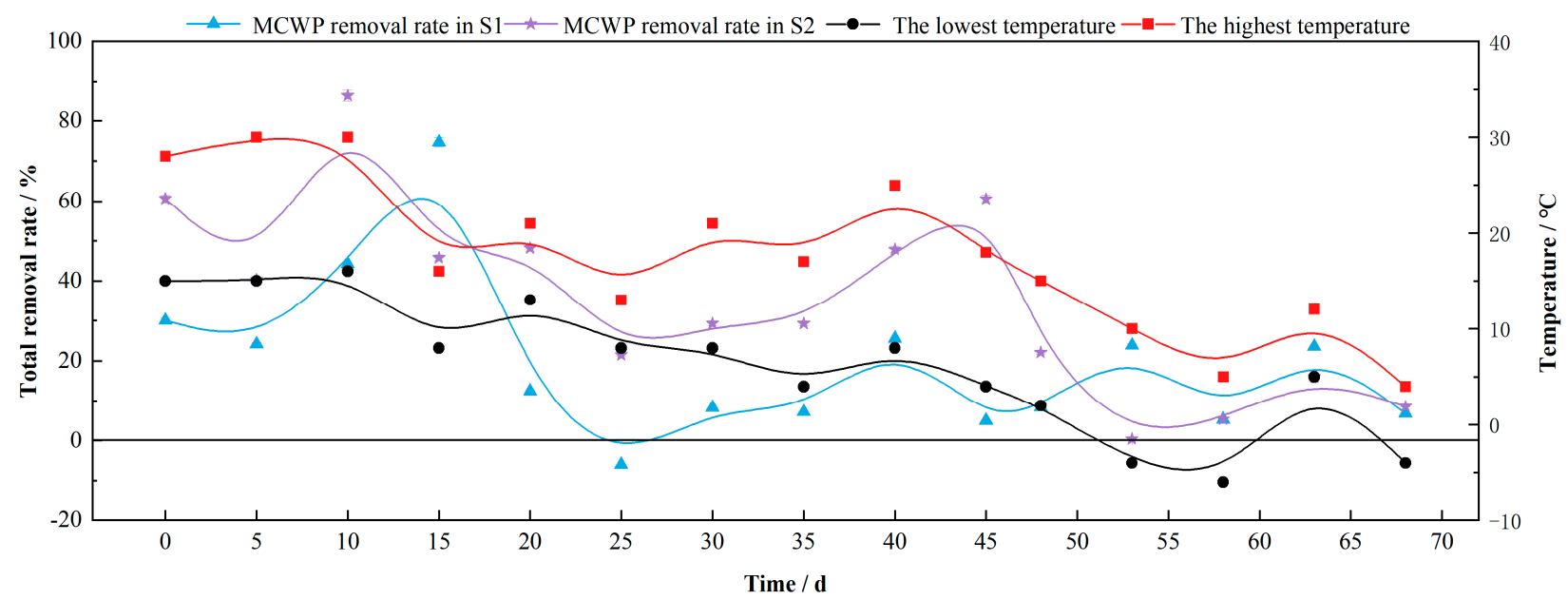

Figure 9. The total TN removal rate and temperature change with time.

The total TN removal rate in S1 and S2 was set as group A, and the daily minimum temperature and the daily maximum temperature were set as group $\mathrm{B}$. Then, a canonical correlation analysis was conducted. The correlation coefficient was $0.835(p<0.05)$, and $\mathrm{A}=0.002$ the total TN removal rate in S1-1.001 the total TN removal rate in S2, B $=-0.352$ the lowest temperature -0.669 the daily highest temperature. Therefore, the daily highest temperature was the major determinant influencing the total TN removal rate in MCWPs. The effect of the daily maximum temperature on the total TN removal efficiency in S2 with high influent COD was more significant than that of S1. In addition, the daily highest temperature showed a highly positive correlation with the total TN removal rate in S2 $(p<0.01)$. The relationship between the temperature and nitrogen removal was studied earlier. A study by Huang et al. [21] used the rate constant equation relative to the air temperature, $K_{T}=0.1053 \times(0.9941)^{(T-20)}$, and predicted the TN content in the outflow of CW. However, the equation was only applicable to predicting the effluent TN concentration under the different HRTs at a specific temperature. It cannot reflect the effect of the temperature change on the $\mathrm{TN}$ concentration of the effluent. This is not surprising because HRT and temperature are two important factors that affect the nitrogen removal effect in CWs. In this experiment, under an HRT of 4.65 days, the relationship between the total removal rate in S1 and $\mathrm{S} 2$ and the highest daily temperature was analyzed. The nonlinear fitting curve is shown in Figure 10, where $x$ is the daily maximum air temperature in ${ }^{\circ} \mathrm{C}$ $\left(4{ }^{\circ} \mathrm{C}<x<30^{\circ} \mathrm{C}\right)$ and $\mathrm{y}$ is the total TN removal efficiency in $\mathrm{S} 1$ and $\mathrm{S} 2$ in $\%$.

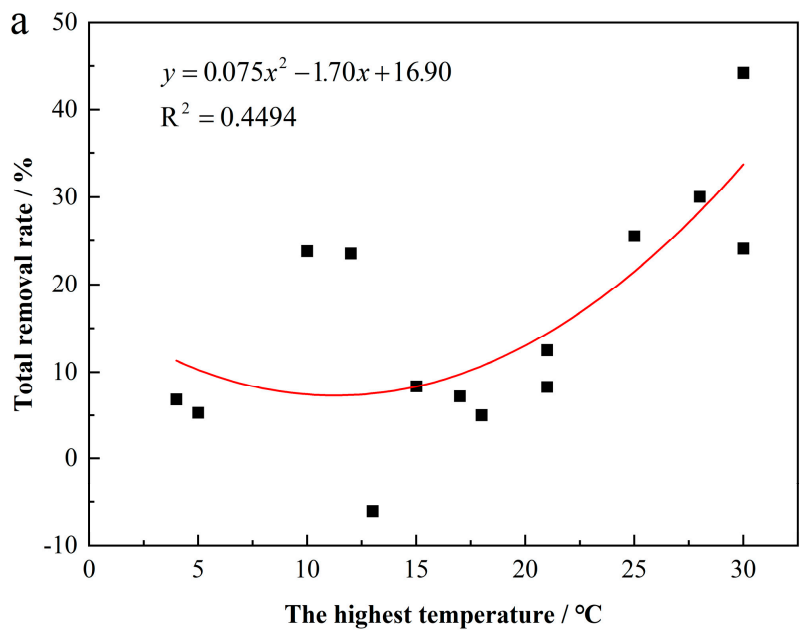

Figure 10. Cont. 


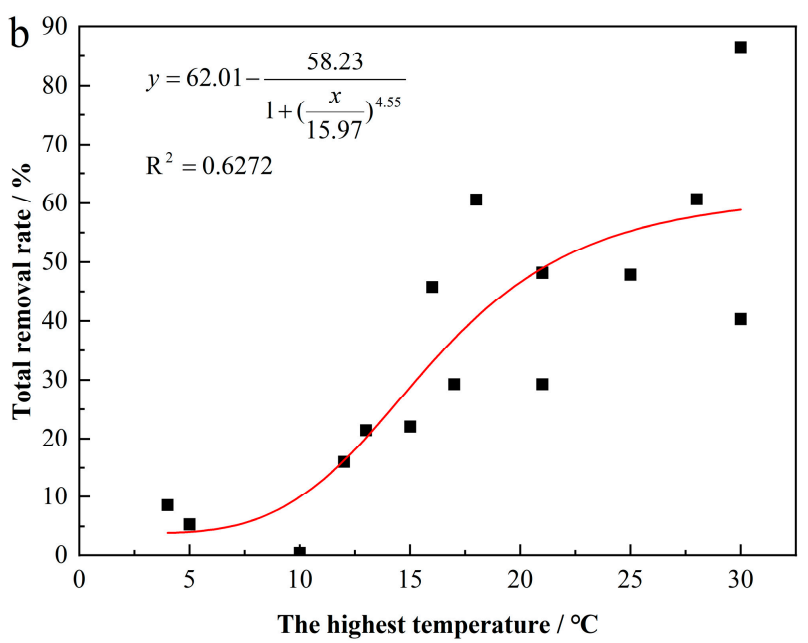

Figure 10. Fitting curve of the total TN removal rate and the daily highest temperature: (a) S1 and (b) S2.

There are many nitrogen removal mechanisms in CWs. Nitrification and denitrification are considered to be the primary pathways in the microbial nitrogen cycle network. Other factors, such as the role of plants and substrates, are generally considered to make a small contribution to the nitrogen removal process. Changes in temperature affect the above nitrogen removal pathways in CWs. Reportedly, one of the reasons why CWs in winter still performed well was that the average winter water temperature was still above the threshold temperature for the denitrification reaction $\left(5^{\circ} \mathrm{C}\right)$. When the temperature was below $5{ }^{\circ} \mathrm{C}$, the denitrification reaction almost stopped [16,79]. Under low-temperature stress, microorganisms secrete a large amount of extracellular polymeric substances that attach to the surface of the substrate [80], which hinders the uptake of organic matter by microorganisms and inhibits the denitrification process. In addition, using anammox is also a key method for nitrogen removal in CWs. Anammox was inhibited when the temperature was less than $15^{\circ} \mathrm{C}$. Anammox was negligible when the temperature was less than $10{ }^{\circ} \mathrm{C}$ [81]. TN can also be effectively removed by substrate adsorption, but the stability of adsorption removal is poor. For example, the effect of the temperature on zeolite adsorption was reflected in the internal and external diffusion of particles [82]. A lowtemperature environment is not conducive to nitrogen overcoming liquid film resistance on the zeolite surface, which hinders the migration of nitrogen along zeolite micropores to its interior, resulting in a reduction in the available surface adsorption sites [83]. In addition, since the adsorption of nitrogen by zeolite is an endothermic reaction, a low temperature would reduce the adsorption capacity of wetland substrates. At a low temperature of $5{ }^{\circ} \mathrm{C}$, the adsorption capacity of zeolite was much less than that at normal temperatures [84]. In other words, low temperature was not conducive to the adsorption of nitrogen by zeolite. To meet their own growth needs, plants would also utilize the nitrogen in wastewater. The highest contribution of plant absorption to TN removal was less than $18 \%$ [85]. As affected by low temperature, the content of nitrogen in the soil substrate that can be directly absorbed by plants would be significantly reduced. In addition, the metabolism and enzyme activity in the plants would decrease under low temperatures. The plants would no longer absorb nutrients, eventually resulting in wilting and death.

\section{Conclusions}

This work is a pilot study conducted before the construction of the actual wetlandpond project to evaluate the influent substrate concentration effect on the nitrogen removal efficiency when the "front ecological oxidation ponds, two-stage HSCWs and SFCWs as the core and post-submerged plant ponds" process is used to treat actual low-C/N ratio river water without adding additional carbon sources. This study lays a theoretical foundation 
for the long-term operation of wetland projects and the adoption of effective measures to improve nitrogen removal. Two MCWPs were constructed to investigate the effect of different substrate concentrations on nitrogen removal in micropolluted water with a fixed $\mathrm{C} / \mathrm{N}$ ratio from summer to winter in the field. The results indicate that the higher COD in the influent of S2 is conducive to the removal of nitrogen (34.84\%). Among these units, the TN removal effect was palpable in SFCWs and SPPs. The average removal efficiencies in the SFCW and SPP of S1 and S2 were $7.82 \%$ and $4.86 \%$ and $13.79 \%$ and $18.31 \%$, respectively. In addition, the daily highest temperature had a high correlation with the total TN removal rate in $\mathrm{S} 2$. The $\mathrm{C} / \mathrm{N}$ ratio was the most significant factor for the nitrogen removal effect in SFCWs. The TN removal rate in SFCWs was negatively related to the COD in the influent. The organic matter secreted by plant roots and dissolved by plant litter in SFCWs with high-density planting was the primary component of the carbon source for denitrification and was an important reason for its significant nitrogen removal effect. This paper provides valuable experience for the study of seasonal nitrogen removal variation in actual low- $\mathrm{C} / \mathrm{N}$ river water by $\mathrm{CW}$-coupled ponds, reveals the link between air temperature and nitrogen removal efficiency, and makes it possible to predict effluent nitrogen concentration simply and conveniently by following the change of temperature during practical projects.

Supplementary Materials: The following are available online at https:/ /www.mdpi.com/article/10 .3390/su132212456/s1, Figure S1: The schematic diagrams: (a) HSCW; (b) SFCW, Figure S2: Changes in plant height in the two-stage HSCWs and SFCWs: (a) S1 system; (b) S2 system.

Author Contributions: H.L. conceived and designed the experiments. T.W. and H.L. performed the experiments. T.W., H.L., L.X., X.Z. and F.L. analyzed and interpreted the data. T.W. was a major contributor to writing the manuscript. S.L. funded the work. All authors have read and agreed to the published version of the manuscript.

Funding: This research was funded by the Ministry of Science and Technology of China (No. 2015FY110900), the National Natural Science Foundation of China (No. 41877409), and the Major Science and Technology Program for Water Pollution Control and Treatment of China (No. 2018ZX07208008).

Institutional Review Board Statement: Not applicable.

Informed Consent Statement: Not applicable.

Data Availability Statement: The data are available from the corresponding author upon reasonable request.

Conflicts of Interest: The authors declare no competing interest.

\section{References}

1. Wilbers, G.; Becker, M.; Nga, L.T.; Sebesvari, Z.; Renaud, F.G. Spatial and temporal variability of surface water pollution in the Mekong Delta, Vietnam. Sci. Total Environ. 2014, 485, 653-665. [CrossRef]

2. Zhou, W.L.; Liu, X.; Dong, X.J.; Wang, Z.; Yuan, Y.; Wang, H.; He, S.B. Sulfur-based autotrophic denitrification from the micro-polluted water. J. Environ. Sci. 2016, 44, 180-188. [CrossRef] [PubMed]

3. Haas, M.B.; Guse, B.; Fohrer, N. Assessing the impacts of best management practices on nitrate pollution in an agricultural dominated lowland catchment considering environmental protection versus economic development. J. Environ. Manag. 2017, 196, 347-364. [CrossRef] [PubMed]

4. Paredes, I.; Ramírez, F.; Forero, M.G.; Greena, A.J. Stable isotopes in helophytes reflect anthropogenic nitrogen pollution in entry streams at the Doñana World Heritage Site. Ecol. Indic. 2019, 97, 130-140. [CrossRef]

5. Sajedi-Hosseini, F.; Malekian, A.; Choubin, B.; Rahmati, O.; Cipullo, S.; Coulon, F.; Pradhan, B. A novel machine learning-based approach for the risk assessment of nitrate groundwater contamination. Sci. Total Environ. 2018, 644, 954-962. [CrossRef] [PubMed]

6. Carvalho, P.N.; Arias, C.A.; Brix, H. Constructed wetlands for water treatment: New developments. Water 2017, 9, 397. [CrossRef]

7. Ilyas, H.; Masih, I. The performance of the intensified constructed wetlands for organic matter and nitrogen removal: A review. J. Environ. Manag. 2017, 198, 372-383. [CrossRef]

8. Zeng, Y.G. Research on Removal Characteristics of Pollutants in Slightly Polluted Water by Constructed Wetland System; Chongqing University: Chongqing, China, 2010. 
9. Huang, L.; Gao, X.; Guo, J.S.; Ma, X.X.; Liu, M. Study on the Purification Efficiency of Micro-polluted River Treated by Subsurface Horizontal Flow Constructed Wetlands. Procedia Environ. Sci. 2011, 10, 908-913. [CrossRef]

10. Ye, F.; Li, Y. Enhancement of nitrogen removal in towery hybrid constructed wetland to treat domestic wastewater for small rural communities. Ecol. Eng. 2009, 35, 1043-1050. [CrossRef]

11. Xu, M.; Liu, W.J.; Li, C.; Xiao, C.; Ding, L.L.; Xu, K.; Geng, J.J.; Ren, H.Q. Evaluation of the treatment performance and microbial communities of a combined constructed wetland used to treat industrial park wastewater. Environ. Sci. Pollut. Res. 2016, 23, 10990-11001. [CrossRef]

12. Saeed, T.; Sun, G.Z. A review on nitrogen and organics removal mechanisms in subsurface flow constructed wetlands: Dependency on environmental parameters, operating conditions and supporting media. J. Environ. Manag. 2012, 112, 429-448. [CrossRef]

13. Green, M.B. Experience with establishment and operation of reed bed treatment for small communities in the UK. Wetl. Ecol. Manag. 1996, 4, 147-158. [CrossRef]

14. Vymazal, J. Removal of nutrients in various types of constructed wetlands. Sci. Total Environ. 2007, 380, 48-65. [CrossRef] [PubMed]

15. Liu, C.J.; Xie, J.Z.; Song, M.L.; Gao, Z.L.; Zheng, D.X.; Liu, X.; Ning, G.H.; Cheng, X.; Bruning, H. Nitrogen removal performance and microbial community changes in subsurface wastewater infiltration systems (SWISs) at low temperature with different bioaugmentation strategies. Bioresour. Technol. 2018, 250, 603-610. [CrossRef] [PubMed]

16. Lu, S.Y.; Jin, X.C.; Yu, G. Nitrogen removal mechanism of constructed wetland. Acta Ecologica Sinica 2006, 26, 2670-2677. [CrossRef]

17. Yang, X.L.; Ye, F.; Song, H.L.; Wang, A.H. Enhanced biological nitrogen removal at low-temperature based on operation data of wastewater treatment plants. China Water Wastewater 2009, 25, 82-85,88. [CrossRef]

18. Hwang, J.H.; Oleszkiewicz, J.A. Effect of cold-temperature shock on nitrification. Water Environ. Res. 2007, 79, 964-968. [CrossRef]

19. Zheng, Y.C.; Wang, X.C.; Xiong, J.Q.; Liu, Y.J.; Zhao, Y.Q. Hybrid constructed wetlands for highly polluted river water treatment and comparison of surface-and subsurface-flow cells. J. Environ. Sci. 2014, 26, 35-42. [CrossRef]

20. Yang, Y.L.; Lu, J.L.; Yu, H.K.; Yang, X.L. Characteristics of disinfection by-products precursors removal from micro-polluted water by constructed wetlands. Ecol. Eng. 2016, 93, 262-268. [CrossRef]

21. Huang, J.; Reneau, R.B., Jr.; Hagedom, C. Nitrogen removal in constructed wetlands employed to treat domestic wastewater. Water Res. 2000, 34, 2582-2588. [CrossRef]

22. Ding, Y.; Wang, W.; Wang, Y.H.; Song, X.S. Effects of C/N ratio of different kinds of influent on the nitrogen removing effectiveness in horizontal subsurface flow constricted wetland. Ind. Water Treat. 2014, 34, 29-32.

23. Wu, J.; Zhang, J.; Jia, W.L.; Xie, H.J.; Gu, R.R.; Li, G.; Gao, B.Y. Impact of COD/N ratio on nitrous oxide emission from microcosm wetlands and their performance in removing nitrogen from wastewater. Bioresour. Technol. 2009, 100, 2910-2917. [CrossRef] [PubMed]

24. Sun, H.W.; Guo, Y.; You, Y.J.; Song, X.R.; Meng, Q.L.; Hao, H.F. Denitrification characteristic of microbial population tamed at different $\mathrm{C} / \mathrm{N}$ ratios. Environ. Chem. 2014, 33, 770-775. [CrossRef]

25. Guo, J.; Li, Z.F.; Zhu, Q.L.; Cui, L.H. Nitrogen removal of urban river water by ecological pond-constructed wetland-ecological pond hybrid system. Trans. CSAE 2011, 27, 191-195. [CrossRef]

26. Huang, J.H.; Mo, W.R.; Tian, S.L.; Peng, F.Q.; Nie, F.; Zhou, X.Y. Oxidation Pond/Constructed Wetland for Treatment of Urban Polluted River Water. China Water Wastewater 2011, 27, 35-38. [CrossRef]

27. Gorito, A.M.; Ribeiro, A.R.; Almeida, C.M.R.; Silva, A.M.T. A review on the application of constructed wetlands for the removal of priority substances and contaminants of emerging concern listed in recently launched EU legislation. Environ. Pollut. 2017, 227, 428-443. [CrossRef] [PubMed]

28. Chen, H.J. Surface-flow constructed treatment wetlands for pollutant removal: Applications and perspectives. Wetlands 2011, 31, 805-814. [CrossRef]

29. Wang, X.O.; Tian, Y.M.; Zhao, X.H.; Peng, S.; Wu, Q.; Yan, L.J. Effects of aeration position on organics, nitrogen and phosphorus removal in combined oxidation pond-constructed wetland systems. Bioresour. Technol. 2015, 198, 7-15. [CrossRef]

30. Stein, O.R.; Hook, P.B. Temperature, plants, and oxygen: How does season affect constructed wetland performance? J. Environ. Sci. Health 2005, 40, 1331-1342. [CrossRef]

31. Cooper, P. The performance of vertical flow constructed wetland systems with special reference to the significance of oxygen transfer and hydraulic loading rates. Water Sci. Technol. 2005, 51, 81-90. [CrossRef]

32. Rossmann, M.; Matos, A.T.; Abreu, E.C.; Silva, F.F.; Borges, A.C. Effect of influent aeration on removal of organic matter from coffee processing wastewater in constructed wetlands. J. Environ. Manag. 2013, 128, 912-919. [CrossRef]

33. Zhang, R.S.; Li, G.H.; Zhou, Q.; Zhang, X. Effects of Plants on Nitrogen/Phosphorus Removal in Subsurface Constructed Wetlands. Environ. Sci. 2005, 26, 83-86. [CrossRef]

34. Zhao, D.H.; Zhang, M.; Liu, Z.; Sheng, J.; An, S.Q. Can cold-season macrophytes at the senescence stage improve nitrogen removal in integrated constructed wetland systems treating low carbon/nitrogen effluent? Bioresour. Technol. 2018, 265, 380-386. [CrossRef]

35. Ji, B.; Kang, P.Y.; Wei, T.; Chang, Y.T.; Qiao, S.X.; Zhao, Y.Q. Removal and Enhancement of Nitrogen in Constructed Wetlands in Cold Climate: A Review. China Water Wastewater 2019, 35, 35-40. [CrossRef]

36. Lu, S.Y.; Zhang, P.Y.; Yu, G.; Zhu, W.P.; Xiang, C.S. The contaminants release rule of Zizania caduciflora, Phragmites austrails and Eichhornia crassipes. China Environ. Sci. 2005, 25, 554-557. [CrossRef] 
37. Verhofstad, M.J.J.M.; Poelen, M.D.M.; van Kempen, M.M.L.; Bakker, E.S.; Smolders, A.J.P. Finding the harvesting frequency to maximize nutrient removal in a constructed wetland dominated by submerged aquatic plants. Ecol. Eng. 2017, 106, 423-430. [CrossRef]

38. Demars, B.O.L.; Edwards, A.C. Tissue nutrient concentrations in aquatic macrophytes: Comparison across biophysical zones, surface water habitats and plant life forms. Chem. Ecol. 2008, 24, 413-422. [CrossRef]

39. Zuidam, J.P.V.; Peeters, E.T. Occurrence of macrophyte monocultures in drainage ditches relates to phosphorus in both sediment and water. SpringerPlus 2013, 2, 564. [CrossRef] [PubMed]

40. Tang, Y.Y.; Harpenslager, S.F.; Van Kempen, M.M.L.; Verbaarschot, E.J.H.; Loeffen, L.M.J.M.; Roelofs, J.G.M.; Smolders, A.J.P.; Lamers, L.P.M. Aquatic macrophytes can be used for wastewater polishingbut not for purification in constructed wetlands. Biogeosciences 2017, 14, 755-766. [CrossRef]

41. Dong, X.F.; Wang, T.; Lu, S.Y.; Lu, H.B.; Li, J.X.; Li, X.; Xiao, L.P. Concentration Effect on the treatment of micropollutant in river with multistage constructed wetland-pond systems. Acta Sci. Circumstantiae 2021, 41, 3563-3577. [CrossRef]

42. Zhang, Y.; Wang, X.P.; Xing, J.L.; Xie, H.J.; Shi, Y.; Guo, W. Biological Nutrients Removal from Simulated Wastewater with Low Carbon-to-Nitrogen Ratio in a New Submerged Composite Membrane-Nitrifying/Denitrifying Bioreactor. Technol. Water Treat. 2017, 43, 79-84. [CrossRef]

43. Cao, F.H.; Luo, Z.F.; Zhou, D.; Zeng, R.J.; Wang, Y.M. Hydroxyethylcellulose-graft-poly(2-(dimethylamino)ethyl methacrylate) as physically adsorbed coating for protein separation by CE. Electrophoresis 2011, 32, 365-374. [CrossRef] [PubMed]

44. Lu, S.L.; Hu, H.Y. Study on Denitrification Capacity of Constructed Wetlands. China Water Wastewater 2008, 24, 63-69.

45. Vymazal, J.; Brix, H.; Cooper, P.F.; Haberl, R.; Perfler, R.; Laber, J. Removal Mechanisms and Types of Constructed Wetlands; Backhuys Publishers: Leiden, The Netherlands, 1998; pp. 17-66.

46. Gerke, S.; Baker, L.A.; Xu, Y. Nitrogen transformations in a wetland receiving lagoon effluent: Sequential model and implications for water reuse. Water Res. 2001, 35, 3857-3866. [CrossRef]

47. Fleming-Singer, M.S.; Horne, A.I. Enhanced nitrate removal efficiency in wetland microcosms using an episediment layer for denitrifi cation. Environ. Sci. Technol. 2002, 36, 1231-1237. [CrossRef] [PubMed]

48. Verhoeven, J.T.A.; Meuleman, A.F.M. Wetlands for wastewater treatment: Opportunities and limitations. Ecol. Eng. 1999, $12,5-12$. [CrossRef]

49. Mucha, A.P.; Almeida, C.M.R.; Bordalo, A.A.; Vasconcelos, M.T.S.D. LMWOA (low molecular weight organic acid) exudation by salt marsh plants: Natural variation and response to Cu contamination. Estuar. Coast. Shelf Sci. 2010, 88, 63-70. [CrossRef]

50. Wang, Y.Y.; Fang, L.; Lin, L.; Luan, T.G.; Tam, N.F.Y. Effects of low molecular-weight organic acids and dehydrogenase activity in rhizosphere sediments of mangrove plants on phytoremediation of polycyclic aromatic hydrocarbons. Chemosphere 2014, 99 , 152-159. [CrossRef]

51. Elefsiniotis, P.; Wareham, D.G.; Smith, M.O. Use of volatile fatty acids from an acid-phase digester for denitrification. J. Biotechnol. 2004, 114, 289-297. [CrossRef]

52. Li, Z.G.; Li, L.M.; Pan, Y.H.; Wu, S.C. Influence of the root exudates of wheat shoots on the denitrifiers in rhizosphere. Acta Pedol. Sin. 1995, 32, 408-413.

53. Zhang, H.; Chen, G.R.; Wu, Z.B.; Deng, J.Q. The study on the relationship between N, P removing rates and the distribution of bacteria in two artificial wetlands. J. HuaZhong Norm. Univ. (Nat. Sci.) 1999, 3, 575-578. [CrossRef]

54. Jing, X.Y.; Yang, D.J. Nitrogen removal and nitrogen-transformation bacteria in Cyperus alternifolius constructed wetland. Ecol. Sci. 2004, 23, 89-91. [CrossRef]

55. Liu, W.; Qiu, J.R.; Wei, Z.B.; Wu, Q.T. Effects of different plants and plant root exudates on wastewater purification. Chin. J. Environ. Eng. 2009, 3, 971-976.

56. Salvato, M.; Borin, M.; Doni, S.; Macci, C.; Ceccanti, B.; Marinari, S.; Masciandaro, G. Wetland plants, micro-organisms and enzymatic activities interrelations in treating N polluted water. Ecol. Eng. 2012, 47, 36-43. [CrossRef]

57. Christ, M.J.; David, M.B. Temperature and moisture effects on the production of dissolved organic carbon in a spodosol. Soil Biol. Biochem. 1996, 28, 1191-1199. [CrossRef]

58. Zhai, X.; Piwpuan, N.; Arias, C.A.; Headley, T.; Brix, H. Can root exudates from emergent wetland plants fuel denitrification in subsurface flow constructed wetland systems? Ecol. Eng. 2013, 61, 555-563. [CrossRef]

59. Zhang, J.; Deng, H.G.; Wu, A.Q.; Chen, S.Y.; Wang, D.Q. Decomposition of Potamogeton crispus and its effect on the aquatic environment of Dongping Lake. Acta Sci. Circumstantiae 2013, 33, 2590-2596. [CrossRef]

60. Wen, Y.; Chen, Y.; Zheng, N.; Yang, D.H.; Zhou, Q. Effects of plant biomass on nitrate removal and transformation of carbon sources in subsurface-flow constructed wetlands. Bioresour. Technol. 2010, 101, 7286-7292. [CrossRef]

61. Si, J.; Xing, Y.; Lu, S.Y.; Jin, X.C.; Hu, X.Z.; Zhang, Y.A.; Bao, Y.W. Release Rule Research of Submerged Plants with Temperature Impact in Contabescence. Chin. Agric. Sci. Bull. 2009, 25, 217-223.

62. Li, Y.F.; Liu, J.; Wang, X.D.; Sun, H.C.; Guan, X.Y. Application and Research of Vertical Constructed Wetland in Cold Areas. J. Shenyang Jianzhu Univ. (Nat. Sci.) 2006, 22, 281-284. [CrossRef]

63. Wang, D.; Li, R.B. The artificial wetland system and its application research on waste-water treatment in northern area. Shanxi Archit. 2005, 32, 172-173. [CrossRef]

64. Zhang, X.L.; Zhou, L. Treating municipal sewage with artifical marsh technique applied in the north. Environ. Eng. 2005, 23, 23-26. [CrossRef] 
65. Li, Y.P.; Zhang, H.K.; Zhu, L.Q.; Chen, H.W.; Du, G.C.; Gao, X.; Pu, Y.S. Evaluation of the long-term performance in a large-scale integrated surface flow constructed wetland-pond system: A case study. Bioresour. Technol. 2020, 309, 123310. [CrossRef] [PubMed]

66. Kadlec, R.H.; Wallace, S.D. Treatment Wetlands, 2nd ed.; CRC Press: Boca Raton, FL, USA; Taylor \& Francis Group: Abingdon, UK, 2009; Volume 242, pp. 285-304.

67. Vymazal, J. The use of hybrid constructed wetlands for wastewater treatment with special attention to nitrogen removal: A review of a recent development. Water Res. 2013, 17, 4795-4811. [CrossRef] [PubMed]

68. Mclatchey, G.P.; Reddy, K.R. Regulation of organic matter decomposition and nutrient release in a wetland soil. J. Environ. Qual. 1998, 27, 1268-1274. [CrossRef]

69. Brinson, M.M.; Lugo, A.E.; Brown, S. Primary productivity, decomposition and consumer activity in freshwater wetlands. Annu. Rev. Ecol. Syst. 2003, 12, 123-161. [CrossRef]

70. Brock, T.C.M.; Huijbregts, C.A.M.; Van de Steeg-Huberts, M.J.H.A.; Vlassak, M.A. In situ studies on the breakdown of Nymphoides peltata (Gmel.) O. Kuntze (Menyanthaceae); Some methodological aspects of the litter bag technique. Hydrobiol. Bull. 1982, 16, 35-49. [CrossRef]

71. Cheesman, A.W.; Turner, B.L.; Inglett, P.W.; Reddy, K.R. Phosphorus transformations during decomposition of wetland macrophytes. Environ. Sci. Technol. 2010, 44, 9265-9271. [CrossRef]

72. Serna, A.; Richards, J.H.; Scinto, L.J. Plant decomposition in wetlands: Effects of hydrologic variation in a re-created everglades. J. Environ. Qual. 2013, 42, 562-572. [CrossRef] [PubMed]

73. Vymazal, J.; Kröpfelová, L. Wastewater Treatment in Constructed Wetlands with Horizontal Sub-surface Flow; Springer Science \& Business Media B.V: Dordrecht, The Netherlands, 2008.

74. Wang, S.Y.; Wang, W.D.; Liu, L.; Zhuang, L.J.; Zhao, S.Y.; Su, Y.; Li, Y.X.; Wang, M.Z.; Wang, C.; Xu, L.Y.; et al. Microbial nitrogen cycle hotspots in the plant-bed/ditch system of a constructed wetland with $\mathrm{N}_{2} \mathrm{O}$ mitigation. Environ. Sci. Technol. 2018, 52, 6226-6236. [CrossRef]

75. Kits, K.D.; Sedlacek, C.J.; Lebedeva, E.V.; Han, P.; Bulaev, A.; Pjevac, P.; Daebeler, A.; Romano, S.; Albertsen, M.; Stein, L.Y.; et al. Kinetic analysis of a complete nitrifier reveals an oligotrophic lifestyle. Nature 2017, 549, 269-272. [CrossRef]

76. Fu, G.K.; Wang, M.; Zhang, Z.; Zhou, Q. Reaction Kinetics of three types of constructed wetland for advanced domestic wastewater treatment. J. Civ. Archit. Environ. Eng. 2012, 34, 111-117. [CrossRef]

77. Domozych, D.S.; Domozych, C.R. Desmids and biofilms of freshwater wetlands: Development and microarchitecture. Microb. Ecol. 2008, 55, 81-93. [CrossRef] [PubMed]

78. Roeselers, G.; Loosdrecht, M.C.M.V.; Muyzer, G. Phototrophic biofilms and their potential applications. J. Appl. Phycol. 2008, 20, 227-235. [CrossRef] [PubMed]

79. Lu, S.Y.; Zhang, P.Y.; Jin, X.C.; Xiang, C.S.; Gui, M.; Zhang, J.; Li, F.M. Nitrogen removal from agricultural runoff by full-scale constructed wetland in China. Hydrobiologia 2009, 621, 115-126. [CrossRef]

80. Wen, Z.D.; Wu, W.M.; Ren, N.Q.; Gao, D.W. Synergistic effect using vermiculite as media with a bacterial biofilm of Arthrobacter sp. for biodegradation of di-(2-ethylhexyl) phthalate. J. Hazard Mater 2016, 304, 118-125. [CrossRef]

81. Wang, L.; Li, T. Effects of seasonal temperature variation on nitrification, anammox process, and bacteria involved in a pilot-scale constructed wetland. Environ. Sci. Pollut. Res. 2015, 22, 3774-3783. [CrossRef]

82. Yang, Y.; Zhao, Y.; Liu, R.; Morgan, D. Global development of various emerged substrates utilized in constructed wetlands. Bioresour. Technol. 2018, 261, 441-452. [CrossRef]

83. Zhao, G.Y.; Zhou, Q. Adsorption of phosphrous from wastewater onto zeolite. Technol. Water Treat. 2007, 33, 34-37. [CrossRef]

84. Cao, X. Investigation of Efficiency for Removal of Ammonia-Nitrogen by Biological Aerated Filter from Low Temperature and Micropolluted Raw Water; Harbin Institute of Technology: Harbin, China, 2017.

85. Li, L.F.; Nian, Y.G.; Jiang, G.M. Contribution of Macrophytes Assimilation in Constructed Wetlands to Nitrogen and Phosphorous Removal. Res. Environ. Sci. 2009, 22, 337-342. [CrossRef] 